\title{
A EPIDEMIA DE TIFO EM LORIGA (1927)
}

\author{
Maria Lúcia de Brito Moura*
}

\section{INTRODUÇÃO}

Antes de entrar no espaço mais envolvente do tema em análise penso não ser despropositado tecer algumas breves considerações sobre mudanças importantes que se foram verificando ao longo dos dois últimos séculos e que tiveram repercussões no modo de encarar a doença - e o doente - no mundo ocidental.

Na verdade, a história das doenças funde-se - e confunde-se - na história geral da Humanidade: dos seus medos, das suas crenças, dos seus rituais... e das vitórias sobre os medos e das ousadias de querer conhecer os segredos do mundo e da vida. História da luta contra a doença e contra a morte ou, utilizando a terminologia de Philippe Ariès, "une révolution de la vie et une révolution de la mort" (P. Ariès, 1993:304), conflui na história da ciência, a grande libertadora, aquela que, sobretudo desde o século XVIII, vinha prometendo ao homem a resposta a todas as questões e o fim de todas as angústias.

$O$ homem emancipava-se e emancipava o universo de qualquer poder exterior a si e, crente nas virtudes do cientismo, pensava estar a assistir ao nascer de um tempo novo, materialização do velho sonho de um paraíso, agora transposto do Céu para a Terra. A ciência traria a riqueza, o domínio sobre a doença, a vitória sobre a morte.

No combate prometeico contra esse alguém que detinha o terrivel poder de decisão sobre o momento de cortar o fio das existências, os finais do século passado representaram o grande passo em frente, com a revolução bacteriológica que, reiterando as promessas anteriormente feitas pela ciência, veio revolucionar a concepção da doença, provocando em muitos espíritos estados de exaltação.

* Professora do Ensino Secundário; Mestre em História Contemporânea de Portugal. 
De futuro nada podia ser como dantes. A raiva, a tuberculose, a febre tifóide, já não tinham segredos. A esperança de que todas as doenças podiam ser vencidas num curto prazo parecia legítima. $\mathrm{O}$ homem deteria, finalmente, o domínio sobre a vida e sobre a morte.

Compreende-se o respeito que envolvia essa "médicine triunfante"| e que se manifestava no prestígio que rodeava os oráculos dos novos tempos - os médi$\cos -$, detentores do conhecimento respeitante aos mistérios da existência.

Justifica-se a importância que a higiene foi assumindo para os governantes, considerando que fomentar a "economia das vidas" era tão importante como fomentar a riqueza ${ }^{2}$. Daí a necessidade do controlo administrativo, em ordem à construção de uma sociedade composta por homens saudáveis, felizes e bons com os três adjectivos unidos numa relação de quase sinonímia.

Portugal não esteve à margem das ideias inovadoras que surgiam lá fora $\mathrm{e}$, no final do século passado e inícios deste, assistiu-se ao nascer de diversas instituições de carácter sanitário e assistencial (I. Vaquinhas, 1992:380) - a algumas das quais esteve ligada a rainha $\mathrm{D}$. Amélia - e à publicação de numerosas obras do mesmo cariz. Sendo visíveis as preocupações com a saúde pública nos últimos governos da monarquia, serão, no entanto, os republicanos que, alarmados com a decadência fisiológica da raça mas crentes na perfectibilidade do homem e na possibilidade de construir o homem novo, levarão mais longe a mística da salubridade, pregando uma moral social com uma forte vertente higienista. Tal moral, de carácter laico, contrapunha-se à moral tradicional radicada na Igreja, a qual era acusada de obscurantismo, de prender os cérebros e os corações através do medo e do servilismo frente a um poder exterior ao homem e que, arbitrariamente, decidia acerca dos destinos de cada um, da felicidade ou da desgraça, da saúde ou da doença.

Novos sacerdotes divulgavam a nova doutrina, mais preocupada com a redenção dos corpos que com a das almas ${ }^{3}$. Contudo, o maior apóstolo em Portugal desta nova religião - a Higiene - foi, sem dúvida, Ricardo Jorge, a cuja actuação se ficou a dever em boa parte a vitória sobre a epidemia de peste bubónica que assolou a cidade do Porto em 1899. O grande combatente ao serviço da saúde pública, a que chamava "moralidade física dos povos", no seu entusiasmo religioso elogiava a aç̧ão dos "missionários da salubridade", os novos "evangelistas" que associam, por vezes, "a glória do apostolado" às "palmas do martírio" (A. Leonor Pereira e J. R. Pita, 1993:439-523). No mesmo sentido Miguel Bombarda chamava aos médicos "os grandes e verdadeiros santos que as raças humanas têm de venerar e adorar no mais sagrado dos seus santuários" (idem, ibidem).

Para conseguir levar às populações ignaras as normas que se impunham para bem da saúde e do bem estar, o grande intermediário seria o professor primário. Como tal, os adeptos da nova crença apostaram decididamente na instrução, considerando prioritário derramar entre os povos as Luzes, necessárias na luta contra 
a passividade, filha da ignorância. Era preciso criar escolas onde os professores, quais catequistas de um novo ideal, pregassem a esperança na felicidade dos corpos e incutissem os novos princípios e regras de vida imprescindíveis para alcançar tal desiderato. Tudo isto dentro de um espírito de exaltação patriótica em que se pretendia levantar o esplendor de Portugal.

Compreende-se que a ideologia republicana assentasse sobre esses dois pilares: o professor e o médico, a escola obrigatória e a higiene. $O$ professor de instrução primária deveria intervir em todas as manifestações da vida local, como uma espécie de mediador entre o poder central e as localidades mais longínquas. Uma das suas atribuições mais relevantes seria a de inspirar ao povo o prazer e a utilidade da higiene (António Nóvoa, 1987:608).

Os inícios da República representam o tempo da esperança. Essa esperança na grande viragem reflecte-se na reforma do sistema educativo empreendida pelo Governo Provisório. No ensino primário, de onde foram abolidas as aulas de religião em qualquer dos seus graus - elementar, complementar e superior -, ao lado da leitura, da aritmética, da educação cívica, surgiu uma nova disciplina: a higiene. Previa-se ainda - e a concretização deste desejo mostrar-se-ia mais difícil do que a simples alteração de programas - a instalação de balneários nas escolas. No ensino normal primário, onde seriam preparados os futuros professores, aparecia igualmente a higiene ${ }^{4}$.

Contudo, a crença nas potencialidades da escola onde se construiria o homem novo revelou-se utópica. $\mathrm{A}$ mudança não foi tão rápida como os místicos do $\mathrm{ABC}$ sonhavam e, nos anos trinta, Portugal era o país com mais elevada mortalidade por varíola, difteria e tifo exantemático (F. Silva Correia, 1938:192). Em 1923, num discurso proferido na Faculdade de Medicina de Lisboa para solenizar o centenário do nascimento de Pasteur, Ricardo Jorge confessava a sua frustração, pois que, após "tanto afinco e tanto trabalho desbaratado, o balanço é desanimador", queixando-se dos "Bártolos, Acácios e Pachecos, dos que rondam em torno dos ministros a tolher-lhes as mãos", das "intrigas de gabinetes", em suma (A. Almeida Garrett, 1958:314).

\section{UMA DAS GRANDES AMEAÇAS À SAÚDE PÚBLICA: O TIFO EXAN- TEMÁTICO}

Entre as doenças de carácter epidémico que, nos anos vinte, continuavam a atormentar os portugueses e que ainda faltava vencer, uma das mais ameaçadoras era o tifo exantemático.

Enfermidade infecciosa, contagiosa e epidémica, é conhecida desde a antiguidade, sendo frequentemente confundida com a peste ou com a febre tifóide. A importância do tifo exantemático, nos seus terríveis efeitos, não teria sido 
menor que os da peste negra na história da humanidade. Surgindo associada às más condições de vida, era o mais terrível adversário nos acampamentos militares, onde encontrava ambiente propício à propagação, podendo evidenciar o seu carácter especialmente mortífero e revelar-se decisivo quanto ao resultado de uma batalha e ao futuro político de uma naçãos.

Por ser uma enfermidade característica de guerras e outras situações de miséria, onde as pessoas se acumulavam com condições higiénicas muito deficientes, recebia, entre outras designações, a de febre dos campos de batalha, febre das prisões, febre dos navios e febre dos hospitais. Em Espanha e algumas regiões de Portugal era denominada por tabardilho. A partir do século XIX, por proposta do médico vienense Lucas Schonlein, os médicos passam a chamar a esta doença, para a distinguir de outras apresentando alguns sintomas semelhantes, tifo exantemático.

O portador desta enfermidade, após um período de incubação de cinco a vinte dias, apresentava febre intensa, cara congestionada, conjuntivite, surgindo muitas vezes bronquite e laringite. Pelos sintomas a doença era confundida frequentemente com a gripe.

O mal atacava o aparelho circulatório, provocando manifestações nervosas que se traduziam em grande inquietação e agitação, delírios e alucinações acompanhadas de um estado de torpor (em grego typhus). Podia aparecer meningite, otite, broncopneumonia, tromboflebite com gangrena nas extremidades... No quarto ou quinto dia surgia o exantema: o doente apresentava espalhadas pelo corpo manchas rosadas que iam sofrendo alterações até tomarem um tom castanho, podendo verificar-se a ocorrência de hemorragias.

A explicação para o seu aparecimento foi desconhecida durante muito tempo. E o facto de poder ser facilmente confundida com outras, de carácter menos maligno, facilitava a transmissão. Somente com o avanço da microbiologia foi possível detectar o causador da doença. Em 1909 Charles Nicolle, do Instituto Pasteur de Túnis, descobriu a forma de propagação do tifo através do piolho. Mas foi um brasileiro, Rocha Lima, quem conseguiu isolar o microrganismo responsável, que designou por Recketsia prowazeki, em homenagem a Ricketts e Prowazek, dois cientistas vítimas da luta contra esses agentes responsáveis por epidemias.

Sendo provocada pelo piolho, as pessoas podiam ser contaminadas através de sangue do enfermo ou da poeira contendo fezes do insecto. Ocorria particularmente no inverno, quando a forma de vestir favorecia a proliferação do insecto transmissor?

O conhecimento da origem da doença não significa, só por si, a possibilidade de curar os doentes afectados. Só com a descoberta da vacina, nos anos trinta e, mais tarde, com os antibióticos, a luta contra o tifo exantemático se revelaria eficaz. Até lá, só evitando-se a acção do agente transmissor através do melhoramento 
das condições de higiene e, no caso de a doença surgir, do isolamento dos afectados, se poderia combater.

Não obstante o avanço da propaganda higienista nas primeiras décadas do século, o tifo exantemático continuava a aparecer em Portugal. Em certos anos, pequenos surtos surgiam aqui e além, com maior ou menor gravidade. Nem sempre assumiam a mesma feição, podendo provocar elevada mortalidade ou contentar-se com um número reduzido de vítimas. Talvez por isso, como lamentava Ricardo Jorge, este flagelo, "por desgraça, passa[va] tantas vezes despercebido ao primeiro assomo, confundido com a vulgar febre tifóide". . De 1913 a 1918 verificaram-se casos de tifo, revestindo maior ou menor gravidade, em diversas zonas do Norte de Portugal e também em Lisboa, Seixal, Alenquer (F. S. Correia, 1938:478-479). Em 1918-1919, uma epidemia tomara conta do Porto, tendo-se contado mais de nove mil casos e verificando-se repercussões em Braga e Vila Real (A. Almeida Garrett, 1958:319). Nos anos seguintes raro era o ano em que não se registavam óbitos por tifo exantemático nos distritos da Guarda, Porto, Castelo Branco, Viseu, Lisboa (cidade), Vila Real, Aveiro, Braga e Leiria. A sul da linha que liga Aveiro a Castelo Branco a doença causava poucas vítimas, com excepção de Lisboa (F. S. Correia, 1938:213).

Nas povoações situadas na Serra da Estrela o tifo exantemático era vulgar. Gouveia, Moimenta da Serra, Manteigas, povoações de forte população operária acumulada em moradias pequenas, com condições higiénicas muito deficientes, foram visitadas, com alguma frequência, nos primeiros anos do século (M. L. Moura, 1996:55). Ricardo Jorge, o grande lutador contra as epidemias em Portugal, escreveu em 1927, a propósito da morte de um dos médicos caídos (em Loriga) na luta contra o flagelo:

Nesta plaga da Beira, coração da terra portuguesa, está enraizada de longe uma praga feroz e tenacíssima - o tifo exantemático, o tabardilho de outrora. Rebenta no rincão de vez em quando aqui e além, acendendo-se e apagando-se como o fogo fátuo (Ricardo Jorge, 1927).

Na mesma ocasião, um elemento da sua equipa, referindo-se a esse "vulpino tifo beirão", considerou que ele parecia "retemperar nos ares da Serra a sua virulência e copiar das raposas daqueles montes a astúcia do ataque".

Havia muito tempo Ricardo Jorge denunciava que o mal era sobretudo social. Nesta conjuntura, voltava a lembrar que a "a guerra sem tréguas contra o flagelo traiçoeiro que a cada passo se ceva na população da Beira" exige, para além da vigilância dos responsáveis directos pela saúde pública, o "remédio social contra a pobreza extrema das aldeias e contra os hábitos derivados de tanta miséria" (Ricardo Jorge, 1927). 


\section{LORIGA, A POVOAÇÃO MARTIRIZADA}

Em meados de Maio de 1927, através da imprensa, os portugueses começaram a ser alertados por notícias que lhes davam a conhecer a situação dramática em que se encontravam as gentes de uma localidade do interior montanhoso, no concelho de Seia. Uma terrível febre, diagnosticada bastante tardiamente como tifo exantemático, grassava desde há meses, tendo recrudescido nas últimas semanas, levando aos lares a doença e a morte.

Loriga apresentava condições idênticas às de tantas outras povoações, onde em outros anos o tifo tinha causado muitas vítimas. Situada em plena Serra da Estrela, aí viviam perto de 2500 pessoas ${ }^{10}$. A aceitarmos a informação veiculada pelo Anuário Comercial de Portugal, em 1926 era "a segunda e mais importante freguesia do concelho e uma das principais do distrito (Guarda), pelo seu comércio e indústria têxtil" "11.

A economia tradicional, assente na criação de gado, na agricultura e no artesanato, recuara perante o trabalho nas fábricas que, a partir dos meados do século XIX, foram surgindo, alimentadas pela força das águas da Ribeira de Loriga, que se precipitavam pelas encostas. No entanto, a agricultura subsistia em pequenas courelas, sustentadas, quase milagrosamente, por fortes muros, numa luta insana empreendida por várias gerações contra a montanha. Todo esse labor deu à paisagem em redor de Loriga um aspecto de escadaria circular, descendo em socalcos desde os cimos até ao fundo daquela enorme bacia.

Ao longo do século XIX o milho tornara-se a cultura dominante, embora a batata tivesse um lugar importante nas leiras menos húmidas. $O$ avanço da cultura de milho fora acompanhado pela criação de gado bovino que permanecia, na maior parte do ano, em estabulação, alimentado com folhas de milho e ervas dos prados ${ }^{12}$. Os currais - "palheiras" -, dispersos pelas encostas, serviam igualmente de abrigo aos ovinos e caprinos que forneciam o leite para o queijo.

Em baixo, no fundo do "alguidar"13, ficava a povoação propriamente dita, com as moradias dispostas em "arruamentos [...] não só declivosos mas, sobretudo, muito irregulares e tortuosos". Por carência de habitações as pessoas viviam em espaços acanhados, o que era atribuído à situação topográfica que impedia o desenvolvimento habitacional ${ }^{14}$. Em 1926 havia em Loriga seis fábricas de lanifícios, onde trabalhavam diariamente algumas centenas de operários ${ }^{15}$. Devido à numerosa população assalariada, era frequentemente designada como a "colmeia, formigueiro humano" que vivia "apertada, zumbidora, a mourejar de sol a sol nos campos e nas fábricas"16.

Que muitos dos seus habitantes estavam dependentes do salário que recebiam na fábrica prova-o a decisão tomada pelo Ministro do Trabalho, em 1919, de man- 
melhorar a situação de miséria em que se encontravam os operários, há meses sem trabalho devido à paralisação da indústria ${ }^{17}$.

Terra de trabalho e terra de pobreza, apesar dos apóstolos que desde há anos falavam em justiça social! A situação de carência continua a ser detectada nos anos trinta. Assim, oito anos anos após o surto epidémico de 1927 que enlutou a povoação, em sessão da Junta de Freguesia foi aprovada a contribuição de duzentos escudos para a Caixa Escolar da freguesia, quantia essa que se destinaria à aquisição de bibes destinados às crianças pobres. Tal medida teria talvez como objectivo, não tanto auxiliar as famílias das crianças carenciadas, mas procurar esconder uma triste realidade. É o que pode deduzir-se de outra deliberação tomada no sentido de que se oficiasse ao Director das escolas primárias, sugerindo-lhe a ideia de obrigar todas as crianças que frequentavam as mesmas ao uso do bibe durante as aulas, "acabando-se assim com o vergonhoso espetaculo das crianças andrajosamente vestidas"18.

Contudo, a acreditar nas declarações do Presidente da Junta, nesse ano somente um terço das quatrocentas crianças em idade escolar frequentariam a escola, "enterradas numa casa onde escasseia o ar, a luz e o espaço" 19 . Isto depois de tantos anos de campanha a favor da alfabetização... É que, na verdade, a um grande número de crianças, a partir dos sete anos não se oferecia qualquer alternativa ao trabalho nas fábricas ou nos campos. A explicação para o fracasso da alfabetização está nas más condições de vida.

É de notar ainda que, em 1927, se vivia uma época de crise nos lanifícios que já se arrastava desde os anos anteriores. Algumas empresas haviam suspendido ou restringido a sua laboração ${ }^{20}$. Compreende-se assim que, sem o mínimo daquilo que os higienistas vinham pregando nas últimas décadas, Loriga possuía todas as condições que facilitavam uma explosão de cariz epidémico.

\section{A EPIDEMIA}

Apesar de somente em Maio grande parte da população portuguesa ter entrado em alvoroço devido às notícias sobre a epidemia, já em Outubro do ano anterior se teriam registado casos de tifo exantemático, possivelmente importado da CoviIhã através de dois operários que, "em busca de trabalho, haviam transposto a Serra até Loriga"21. Contudo, a doença não foi desde logo diagnosticada, pois, como já foi dito e se repetia em nota oficiosa, "o morbo muitas vezes se disfarça e se afasta das formas descritas nos livros" ${ }^{\prime 2}$, desnorteando quase sempre o prático, levando-o a crer estar perante gripes paratifóides ou, mesmo, de febres tifóides mais vulgares. As vítimas situavam-se de preferência nas "classes miseráveis"23, especialmente entre as mulheres. 
Até finais de Março como gripe a considerou o Dr. Joaquim Amorim Fonseca, facultativo municipal de Loriga desde há trinta e três anos. O médico de Paranhos da Beira, do mesmo concelho, Dr. Custódio Gomes, igualmente se inclinou para a hipótese de uma "doença de carácter tifóide"24. A moléstia alastrava, pois que, por ausência de medidas de precaução, as pessoas que cuidavam dos doentes iam sendo infectadas. Depois da Páscoa, com o agravar da situação, a ponto de adoecerem sete a oito pessoas por dia, as autoridades locais decidiram apresentar 0 problema às instâncias superiores ${ }^{25}$. Em telegrama dirigido ao Governador Civil, para além de se requererem providências no sentido de se debelar a epidemia, pedia-se socorros para os doentes pobres ${ }^{26}$.

Ajuda pecuniária e pessoal de enfermagem solicitou igualmente o Dr. Simões Pereira que, na qualidade de subinspector de saúde de Seia, se deslocou a Loriga onde, num primeiro diagnóstico, considerou tratar-se de uma febre tifóide, não indo assim contra a opinião dos seus colegas ${ }^{27}$. Auxílio pecuniário pedia igualmente o administrador António Dias que, tendo sido informado da grave situação através do Governo Civil, se deslocou a Loriga, tendo dado ordens à Comissão Administrativa no sentido de que fosse requisitado o leite necessário para o tratamento dos doentes ${ }^{28}$. Em 29 de Abril, num ofício dirigido ao Governador Civil, informava que, desde o princípio do mês, em trinta doentes haviam ocorrido dezasseis óbitos. É significativo que, em outros ofícios com essa mesma data, tenha solicitado um subsídio para alargamento do cemitério da referida povoação, impossibilitado de receber mais cadáveres devido ao extraordinário número de óbitos causados pela epidemia ${ }^{29}$.

Entretanto, advertido pela Direcção Geral de Saúde - a que presidia o experiente Ricardo Jorge -, sobre a possibilidade de se tratar de tifo exantemático e, por outro lado, numa segunda visita, sobressaltado com o aparecimento de um novo foco epidémico de catorze pessoas, o Dr. Simões Pereira concluiu tratar-se realmente dessa terrível doença. Imediatamente, por telegrama, comunicou à Direcção Geral de Saúde. Estava-se a 7 de Maio $^{30}$.

É natural que o pânico se tivesse instalado entre a população que, segundo um jornal da região, via "adejar por sobre as suas cabeças, sob um aspecto tenebroso, as asas da morte" 31 . Se em Março se registaram oito óbitos - quatro vezes mais que no mês de Fevereiro -, em Abril ascenderam a dezasseis. Organizaram-se comissões de pessoas que enviavam telegramas a todas as autoridades, desde o administrador do concelho ao Presidente da República. Também a Junta de Freguesia, presidida por António Cardoso de Moura, envidava todos os esforços para apressar a tomada de medidas. Foram proibidos os ajuntamentos de pessoas. O sino deixou de tocar, não se realizando qualquer acto de culto ${ }^{32}$.

Mas o verdadeiro combate começou a ser travado somente a partir do dia $7 \mathrm{e}$ não podemos deixar de admirar a prontidão e eficiência com que foi organizado o sistema de socorros. 
Se, antes de conhecer as conclusões da investigação do subinspector, a Direcção Geral de Saúde revelara algum interesse disponibilizando uma verba de $2500 \$ 00$ e autorizando a contratação de pessoal de enfermagem no local ${ }^{33}$, uma vez adquirida a certeza de que o inimigo a combater era, realmente, o tifo exantemático, a reacção foi rápida e eficaz.

Talvez não seja exagerado explicar a prontidão e eficiência pelo facto de se encontrar à frente da Direcção Geral de Saúde o notável epidemiologista Ricardo Jorge, habituado a enfrentar problemas deste tipo. Um vagão com cinquenta camas completas, tinas de banho, aparelhos de desinfecção, desinfectantes, fatos e outras roupas, estavam prontos no dia imediato, seguindo sem demora para $o$ lugar a socorrer. Acompanhava o material um chefe de desinfectadores. Para as despesas de combate à epidemia e assistência aos epidemiados, foram disponibilizados $12000 \$ 00$.

Com o objectivo de orientar os trabalhos partiu de Lisboa o inspector de epidemias e futuro Director Geral de Saúde, Dr. José Alberto Faria, acompanhado pelo chefe da Repartição de Saúde, Júlio de Macedo ${ }^{34}$.

A situação com que depararam à chegada, no dia 9, impressionou vivamente Alberto Faria. É o que se depreende de uma carta escrita algum tempo depois, onde afirma:

Daqueles horrorosos dias de Maio de 1927, os dias de Loriga, guardo eu as impressões mais brutalmente cruéis e mais vibrantes de grandeza. Um aglomerado de gente, perdido entre montes, sentindo cada um a dor do vizinho como sua fosse, enleadas as trabalhosas vidas, as de uns com as de outros, como se em única família estivessem agrupados, assistia inerme à fatal dizimação que um mal implacável entre eles ia operando ${ }^{35}$.

Em reunião com as autoridades administrativas e sanitárias do concelho e pessoas de representação da localidade afectada, foram estabelecidos os planos de combate. O subinspector de Saúde é que já não pôde assistir à reunião por se encontrar ele próprio enfermo, acometido pelo terrível mal contra o qual lutava. O Dr. Rocha Santos (mais tarde presidente da Câmara) substituía-o, na qualidade de subinspector interino ${ }^{36}$.

Pois que "as duas grandes armas de combate" seriam o isolamento e a desinfeç̧ão ${ }^{37}$, foi instalado, no curto período de três dias, um hospital para os epidemiados. Para isso, graças à boa vontade dos proprietários, foram ocupados dois edifícios nas proximidades de uma capela dedicada a Nossa Senhora do Carmo nessa altura a necessitar de obras de restauro ${ }^{38}$ - que, naquelas circunstâncias, ficou ao dispor da equipa sanitária que aí estabeleceu o balneário para desparasitação geral. O hospital possuía casa própria para banho, funcionando nas traseiras o posto de desinfecção de roupas.

Para atalhar a propagação do mal organizaram-se visitas sanitárias a casas e fábricas, procedendo-se aí a operações de desinfecção ${ }^{39}$. 
Não deve ter sido fácil montar toda essa operação de socorro. Através da correspondência do administrador podemos acompanhar (e adivinhar) as dificuldades: numa primeira fase a agitação ${ }^{40}$ de um povo que, ao saber da terrível moléstia que tem consigo, ajuíza que as medidas não vêm com a rapidez desejada; depois, a falta de dinheiro e de roupas para os doentes hospitalizados e, relativamente a estes e seus familiares, aquele sentimento - de cada um querer permanecer em sua casa - que o administrador designava como "relutância ignorante do povo"4l.

Entretanto, os primeiros médicos que se haviam defrontado com a doença lutavam agora pelas suas próprias vidas. Primeiro foi o Dr. Simões Pereira. O Dr. José Alberto Faria encontrou-o já doente, na sua residência em Seia, talvez ainda esperançado na cura, - entregue à "assistência permanente de sumidades médicas de Coimbra e Viseu" 42 - mas apresentando a olhos experientes a marca da morte. É o que parece deduzir-se das palavras do inspector que descreve o encontro nestes termos:

E, ao observá-lo de seguida, vejo no pobre colega Simões Pereira, já com cinco dias de febre, o despontar dos primeiros traços do exantema ${ }^{43}$.

O Dr. Amorim Fonseca, o velho e bondoso médico de Loriga, em breve se lhe seguia ${ }^{44}$. É fácil imaginar o alastrar do pânico numa população que se sentia abandonada, sem médico residente e que, através da imprensa nacional, se queixava, talvez injustamente, do subinspector interino que não daria a necessária assistên$\mathrm{cia}^{45}$. Essa situação arrastou-se por três ou quatro dias, só sendo encontrada solução quando, em reunião de facultativos do concelho convocada pelo Presidente da Câmara Municipal, se ofereceu para prestar serviço aos epidemiados o médico de Paranhos da Beira, do mesmo concelho de Seia, Dr. Custódio Gomes de Azevedo ${ }^{46}$. Sendo digno de registo o facto de, nesta conjuntura, com o terrível exemplo das duas vítimas, alguém se apresentar para a frente da luta, é-o ainda mais sabendo-se que este facultativo prescindiu dos seus vencimentos, entregando-os a $O$ Século, que ia acompanhando o evoluir da epidemia, para que este jornal se encarregasse da sua distribuição pelos pobres da freguesia ${ }^{47}$.

No sentido de coordenar os serviços de combate à epidemia e evitar a sua difusão a Direcção Geral de Saúde designou, como Delegado da Inspecção de Epidemias, com autoridade mais alargada a nível regional, o Dr. João da Mota Feliz subinspector de Saúde de Fornos de Algodres -, o qual seguiu no dia 21 de Maio para Loriga ${ }^{48}$. Para essa nomeação não teria sido estranha a experiência deste clínico, porquanto não era a primeira vez que se via em semelhante transe. Em 1910, quando uma epidemia de tifo provocava a sua destruição em Manteigas, oferecera-se para substituir o seu colega Pereira de Matos que adoecera e a quem foi encontrar já agonizante, mais uma vítima do terrível monstro ${ }^{49}$ que, segundo as 
palavras de Ricardo Jorge, "parece ter uma predilecção ferina pela mão do médico" ${ }^{\circ 0}$.

Quanto ao pessoal de enfermagem, os mais qualificados vieram dos hospitais de Lisboa. Alguns integraram-se na comunidade local, conquistando simpatias e sendo ainda hoje conhecidos pelos seus nomes. É o caso do enfermeiro Mesquita que exerceu funções de administrador do hospital e chefe de enfermagem ${ }^{51}$.

Relativamente ao número de mortos por tifo é difícil apresentar valores seguros pois que, até aos finais da segunda quinzena de Maio, a doença não estava devidamente identificada. Somente um estudo comparativo do comportamento da mortalidade em 1927 com os dois anos anteriores nos permitirá extrair algumas conclusões.

\section{ÓBITOS EM LORIGA}

(1925-1927)

\begin{tabular}{|l|c|c|c|}
\hline & 1925 & 1926 & $\mathbf{1 9 2 7}$ \\
\hline Janeiro & 5 & 8 & $\mathbf{2}$ \\
\hline Fevereiro & 3 & 3 & $\mathbf{2}$ \\
\hline Março & 4 & 7 & $\mathbf{8}^{52}$ \\
\hline Abril & 6 & 3 & $\mathbf{1 6}$ \\
\hline Maio & 1 & 2 & $\mathbf{1 8}$ \\
\hline Junho & 1 & 3 & $\mathbf{1 1}$ \\
\hline Julho & 3 & 4 & $\mathbf{7}$ \\
\hline Agosto & 7 & 5 & $\mathbf{9}$ \\
\hline Setembro & 3 & 6 & $\mathbf{3}$ \\
\hline Outubro & 6 & 8 & $\mathbf{4}$ \\
\hline Novembro & 4 & 2 & $\mathbf{2}$ \\
\hline Dezembro & 4 & 8 & $\mathbf{4}$ \\
\hline & & & 86 \\
Total & 47 & 59 & $\mathbf{8 6}$ \\
\hline
\end{tabular}

Fonte: Livro dos Obitos, existente no Arq. Par. Loriga

A partir de Março de 1927 o aumento da mortalidade é visível. O ponto alto verifica-se em Maio, com dezoito óbitos (muito superior aos números registados nos anos anteriores). Mas o número de pessoas contagiadas e que escaparam à morte foi muito superior. Sabemos que, desde a abertura do hospital aos inícios de Junho, num movimento de sessenta isolados se verificou somente um caso de morte. No dia 3 conservavam-se internados vinte e cinco doentes ${ }^{53}$, acabando três deles por sucumbir alguns dias depois ${ }^{54}$. 
A epidemia recuava. Embora continuassem a funcionar rigorosamente os serviços de desinfecção, a batalha estava ganha. A 15 de Junho considerava-se terminado o estado epidémico com as últimas desinfecções das oitocentas casas e de cinco fábricas ${ }^{55}$.

Se, no final, a administração se podia dar por satisfeita com o êxito da operação, sobretudo por ter conseguido suster o surto epidémico evitando que transbordasse para outras localidades, a população enlutada encontrar-se-ia entorpecida, sem conseguir saborear a alegria de ter sobrevivido. Apesar de a doença não ter conseguido atingir grande parte da população, os meses anteriores haviam sido de pesadelo. O medo fizera parte do quotidiano, presente em todos os lares. Quando a vida regressou ao normal poucos seriam os que não tinham perdido um ou mais familiares, um ou mais amigos. Através dos assentos de óbitos - embora não nos informem concretamente acerca da origem da morte quando ela ocorre em casa -, podemos detectar diversos casos de óbitos ocorridos na mesma família. Sem pretender cair no melodrama, mas numa tentativa (talvez vã) de encontrar uma medida-padrão que permita aproximarmo-nos do imensurável, apontarei situações de irmãos que partiram com diferença de poucos dias, como Emília e Hermínia, cujas mortes ocorreram em 5 e 10 de Abril; ou como Maria do Carmo e Benedita, finadas em 13 e 17 de Maio. Também a morte de Urbana, em 29 de Abril, foi em breve seguida da de sua mãe, em 10 de Maio. E depois de Maria José, falecida no hospital de isolamento em 2 de Junho, chegou a vez de sua mãe, que morria no mesmo hospital, em 12 do mesmo mês.

Interessante o facto de grande parte dos óbitos de adultos serem de mulheres. De um de Março a quinze de Junho, entre os falecidos com mais de oito anos, contam-se 27 mulheres e oito homens. A que se poderá atribuir esta diferença? Aos cabelos compridos das mulheres que constituiriam meio propício ao insecto transmissor? Ou antes, ao facto de serem as mulheres que tratavam dos enfermos, podendo ser contagiadas ao socorrerem familiares ou vizinhos?

\section{O ENQUADRAMENTO ADMINISTRATIVO}

Como faz notar Foucault, a sociedade organizada responde à peste com a "ordem", com a "disciplina", com "a organização aprofundada das vigilâncias e dos controles" (Foucault, 1987:175).

Em Loriga as vidas das pessoas foram apanhadas na rede da tecnoburocratização sanitária. Para os enfermos fora imposto o isolamento e, afastados dos vizinhos, familiares e amigos, eram tratados, manipulados por gente estranha, sabedora e eficiente, que ditava regras desconhecidas até então. Possivelmente algumas famílias mostraram pouco espírito de cooperação com as autoridades, não denunciando os seus doentes, descobertos mais tarde pelo pessoal de desin- 
fecção ${ }^{56}$. Como acontece com todos os mecanismos disciplinares, existe uma "desigualdade de posição dos diversos «parceiros» em relação ao regulamento comum" (Foucault, 1987:195). Deste modo, a malha das imposições era suficientemente flexível para permitir que alguns a ela escapassem. O Dr. Amorim da Fonseca, contagiado com o tifo exantemático, não foi sujeito a esse tipo de isolamento, tendo morrido na sua residência ${ }^{57}$. É possível que este caso não fosse único.

Quanto às pessoas a quem a doença poupara até então, nem por isso se encontravam fora do alcance da máquina administrativa. Loriga tornara-se num enorme hospital-prisão, com a população sujeita a um eficiente controlo através de desinfecções e visitas sanitárias aos domicílios. Durante alguns dias, antes de os serviços de desinfecção estarem organizados, não foi permitido sair da localidade. Tal medida, para além do transtorno que causava a muitos, era considerada "vexatória" ${ }^{\prime 58}$. Depois de conseguida a normalização - dentro do excepcional --, quem pretendesse sair teria de submeter-se a revisão $0^{59}$ - o "exame" de que fala Foucault, "controle normalizante [...] que permite qualificar, classificar e punir" (Foucault, 1987:164). Tal exame era acompanhado por todo "um sistema de registro intenso e de acumulação documentária"60, concretizado numa guia sanitária.

Para dificultar as evasões não se permitia a saída das camionetas da carreira, o que afectava em especial a indústria e o comércio ${ }^{61}$. Para aqueles que conseguissem transpor os portões do sistema de vigilância, a suspeita e a discriminação persegui-los-iam lá fora. De pouco valeria a estima e a consideração que até aí gozassem. Desse clima de desconfiança foi vítima o professor de Loriga, Pedro de Almeida, pessoa muito respeitada em Seia, o que não evitou que, num dia em que aí se deslocou, passasse pelo vexame de sentir que os outros fugiam a apertar-lhe a mão ${ }^{62}$.

A morte tornara-se clandestina, pois o sino permanecia silencioso, impedindo a realização dos ritos solidários por parte dos membros da comunidade que, em circunstâncias normais, viriam rezar e chorar pelo que partira. A igreja encerrara, acatando também ela as leis da poderosa higiene que, neste transe, era quem detinha a última palavra. Numa povoação de fortes tradições religiosas e que, nessa hora, somente na religião poderia derramar os seus terrores e procurar a luz de uma esperança, o encerrar da igreja simbolizaria o abandono supremo, o fechar da porta no rosto dos condenados.

Nesta guerra em que todos os campos saíam derrotados, encerrada estava também a escola ${ }^{63}$, esse outro templo da religião laica que muitos sonhavam para religião do futuro.

No respeitante à prática religiosa seria difícil aceitar sem revolta as medidas disciplinadoras. Muitos pensariam em contornar as proibições e, numa outra igreja, ir extravasar angústias ou, até, agradecer a cura de alguém querido. É o que se depreende de um rascunho encontrado (de carta ou telegrama a dirigir ao 
subinspector de saúde e que, tudo leva a crer, teria sido enviado), em que o médico do hospital de isolamento dá a conhecer as suas apreensões relacionadas com uma festa que iria realizar-se em Alvoco da Serra (a oito Kms. de distância), onde se esperava grande aglomeração de gente e à qual "a população de Loriga" pretenderia ir. Não tendo meios para impedir tal, rogava ao seu colega que tomasse providências no sentido de que tal festa não se realizasse pelo perigo que representava para a saúde pública ${ }^{64}$.

Por aqui se pode concluir que a epidemia não transtornava somente as vidas das pessoas de Loriga, mas representava um foco de perturbação para as outras localidades. Também a Semana da Criança, da iniciativa da Liga de Acção Educativa, foi afectada. Estando programada uma festa para o último domingo de Maio, que teria lugar em Seia com a cooperação de todas as escolas do concelho, não se realizou, ficando adiada para "melhor oportunidade", devido ao estado sanitário de Loriga ${ }^{65}$.

O sistema de vigilância não se contentava com as restrições nas liberdades individuais ou com o devassar da privacidade dos lares no círculo restrito de Loriga. No intuito de impedir que o foco epidémico projectasse "faúlhas ao longe", foram tomadas medidas especiais sobre os indivíduos que pretendessem sair de Seia, solicitando-se igualmente o impedimento de licenças aos soldados que "pretendessem passar aquele concelho"66.

\section{AS REPERCUSSÕES NO RESTO DO PAÍS}

A situação de pânico perante o que se passava não ficou circunscrita à zona do concelho - onde não se falava noutra coisa, segundo testemunhos da época - ou, mesmo, dos concelhos limítrofes. A imprensa levava as notícias às outras regiões que, assim, acompanhavam a situação com apreensão e, talvez mesmo, um alarmismo exagerado. É, contudo, natural que a doença dos médicos tivesse despertado a maior ansiedade. A doença do Dr. Simões Pereira e, logo de seguida, a do Dr. Amorim Fonseca, teriam contribuído para esse estado de angústia pois que, afinal, depois de tantas promessas da ciência, nem os próprios médicos, esses novos deuses da laicidade, conseguiam resistir. No dia 21 de Maio $O$ Século noticiava a morte do primeiro ${ }^{67}$ e, logo no dia seguinte, dava a conhecer a do segundo $^{68}$. Se a morte de um médico contagiado pela doença era significativa quanto ao carácter de perigosidade, a morte do segundo acrescentaria consideravelmente o grau de ansiedade, era o sinal de impotência, era a derrota da medicina perante o ente maléfico que, mais dia menos dia, galgaria as montanhas, indo cevar a sua fúria nos grandes aglomerados.

$O$ terror seria ainda acrescido se a imprensa não tivesse passado em silêncio a morte de um outro profissional, o barbeiro José Luiz Amaro Tuna, mais conhe- 
cido por José Farias que, requisitado para cortar o cabelo dos "empestados" 69 do hospital, adoeceu alguns dias depois, vindo a falecer.

É compreensível que uma vaga de medo se espalhasse, ressuscitando terrores antigos, emergindo da profundidade de uma memória onde estavam gravados quadros de multidões empestadas, lembrando que o Antigo Regime de pestes destruidoras não estava assim tão distante. Nestas condições o terror estabelece-se, os fantasmas actuam e o irracional instala-se.

Como acontece em circunstâncias análogas, o boato sobrepor-se-ia às notícias que, aliás, pareciam desencontradas, o que não ajudaria a tranquilizar o público. Enquanto em 19 de Maio $O$ Século, em informação recebida através do seu correspondente em Loriga, noticiava 22 vítimas $^{70}$, o Novidades de 23 do mesmo mês referia-se a quarenta mortos e sessenta contagiados ${ }^{71}$.

Conforme já foi salientado, as dificuldades de circulação fora da sua terra causavam descontentamentos a muitos loriguenses que precisavam de ir tratar da sua vida ou, simplesmente, tentariam escapar à ameaça que sobre eles pendia. Daí que se verificassem transgressões à normalização, com indivíduos tentando romper os limites do proibido. Mas os olhos que vigiavam da torre panóptica ${ }^{72}$ conseguiam ver ao longe e o braço da sua burocracia chegava a todos os recantos. Em 18 de Maio $O$ Século noticiava que um rapazito, chegado recentemente a Sacavém ${ }^{73}$, ido de Loriga, fora conduzido para o hospital do Rego, em Lisboa, o mesmo acontecendo às cerca de vinte pessoas que habitavam na casa onde se acolhera. Esta casa foi convenientemente desinfectada, sendo inutilizados os tabiques que a divi$\operatorname{diam}^{74}$.

Mesmo as pessoas que saíam com os papéis em ordem, isto é, depois de sujeitas a revisão e munidas de guias sanitárias que, em princípio, as livraria de dificuldades, não poderiam andar tranquilos. Exemplo disso é o que se passava em Coimbra onde, nos Paços do Concelho, eram inspeccionados todos os dias, pelo subinspector de saúde, os indivíduos que se deslocavam de Loriga para essa cidade $^{75}$.

Em 30 de Maio, em carta dirigida ao director do hospital de isolamento, o Delegado de Saúde de Coimbra pedia que lhe fossem enviados os duplicados das guias passadas aos que saíssem da localidade, a fim de poderem ser procurados os que não se apresentassem à revisão. Solicitavam-se informações sobre o lugar de residência desses passageiros na cidade ${ }^{76}$.

Alguns dias antes, em 28 de Maio, em telegrama enviado ao director do Hospital de Isolamento de Loriga, o mesmo Delegado de Saúde pedia que o informasse da via de transporte usada por determinado indivíduo saído de Loriga, bem como da hora de chegada a Coimbra, a fim de ser vigiado. Poucos dias depois a mesma autoridade sanitária informou, por ofício, que o dito passageiro seguia novamente para Loriga, devendo chegar no dia 1 de Junho, depois de ter estado em revisão médica nos dias 29,30 e 31 . 
O círculo de suspeição alargara-se e, se numa primeira fase, os habitantes de Loriga poderiam ter motivos de queixa relativamente aos das restantes freguesias do concelho, em breve estes começaram a sentir-se eles próprios vítimas. $\mathrm{O}$ terror instalara-se e espalhavam-se boatos de que o número de vítimas era enorme ${ }^{77}$. Em 24 de Maio a Gazeta de Coimbra afirmava que a epidemia assumia "proporções assustadoras", alastrando para fora da localidade ${ }^{78}$.

No mesmo dia o Diário de Notícias referia-se à epidemia, em notícia que tinha por título "A epidemia no concelho de Seia e limítrofes"79. Alguns dias depois este diário, depois de se referir a três casos de tifo surgidos em Lisboa, aludia a dois rapazes com tifo detectados em Sacavém e que teriam ido de Loriga ${ }^{80}$.

Perante os boatos inquietantes que se espalhavam pelo país, onde se imaginava já todo o concelho "inficionado", o Delegado da Inspecção das Epidemias, Dr. Motta Feliz, fez publicar uma "nota oficiosa" onde se afirmava continuar a epidemia circunscrita a Loriga, não se justificando, por isso, "as precauções tomadas na Covilhã contra os habitantes de Alvoco da Serra". Nos concelhos limítrofes a situação continuava normal, não tendo os casos ocorridos em Gouveia (S. Paio) tido qualquer repercussão. Pedia-se às populações que não se deixassem influenciar por "notícias tendenciosas"81.

Também o subinspector de Saúde, Dr. Rocha Santos, assegurava que a situação em Loriga tendia a normalizar, mantendo-se as desinfecções domiciliares, bem como despiolhamento e balneação. O caso duvidoso ocorrido na Lapa dos Dinheiros (pertencente então à freguesia de S. Romão), de que resultara um óbito, foi prontamente atendido, tendo-se procedido à desinfecção do prédio onde se verificara a ocorrência, assim como dos dois prédios vizinhos e das pessoas que haviam contactado com a pessoa morta ${ }^{82}$.

O pânico conduzia à suspeita, à discriminação, à delação. A máquina da vigilância reproduzia-se. Em Lisboa a polícia, como medida preventiva, isolou no hospital do Rego cinquenta e nove moradores de um prédio situado na Rua Augusto José Vieira. Passados alguns dias reconheceu-se que se tratava de um falso alarme, pelo que foram libertados ${ }^{83}$. Como resposta a uma denúncia, a polícia cercou um prédio na Rua Particular, à Fonte Santa, cujos habitantes, em número de cento e nove, entre homens, mulheres e crianças, foram conduzidos para o hospital e alojados em pavilhões de isolamento onde teriam de permanecer em observação durante dez dias. Como se se tratasse de criminosos, foram separados os homens das mulheres e das crianças. Cinco dias após a detenção quatro deles conseguiram galgar o muro do hospital, não logrando, contudo, alcançar a liberdade. Reconhecidos pelos trajes hospitalares - que funcionavam como marca de exclusão, com o valor simbólico das antigas matracas dos leprosos -, foram devolvidos ao hospital onde continuaram "sob a maior vigilância"84.

Poderemos questionar-nos acerca da isenção e inocência com que se procedia a estas detenções. Em todos os casos detectados trata-se de pessoas pertencentes 
a classes desfavorecidas. Segundo uma moral que tende a estabelecer laços entre saúde e virtude, doença e vício e ainda questão social e questão moral, aqueles que não se integravam dentro dos parâmetros definidos pelos grupos dominantes deveriam ser isolados, tornando-se alvo do aparelho repressivo institucional.

O medo afectava as ligações entre as pessoas, com reflexos nas relações de vizinhança e, porventura, mesmo nas esferas do económico. Tentando sossegar a população, uma nota, emanada da Direcção Geral de Saúde e enviada à Direcção Geral de Segurança Pública e à Direcção Geral dos Hospitais, aludia aos inconvenientes de o pessoal dependente daqueles organismos dar notícias ou informações sobre casos de doenças contagiosas que surgissem em Lisboa e sobre as medidas de prevenção tomadas pelas autoridades sanitárias. Tais informações, quase sempre eivadas de confusões e erros, levantavam alvoroço infundado que, algumas vezes, se tinha reflectido "danosamente nas nossas relações externas" 85 .

\section{HONRAS AOS HERÓIS E MÁRTITES}

A impressão causada pelas mortes de Amorim da Fonseca e Simões Pereira ultrapassou em muito os limites do concelho de Seia.

A morte, só por si, afecta emocionalmente os sobreviventes, conduzindo a um enaltecimento do desaparecido. No respeitante aos dois médicos, o facto de a morte os ter vencido quando, no cumprimento do dever, tentavam auxiliar os outros, conferia-lhes a auréola da santidade e a palma do martírio. Referindo-se ao Dr. Amorim da Fonseca, a quem teve ocasião de apreciar no seu mister, pois chegou a acompanhá-lo nas visitas aos doentes, "pela escuridão daquelas casas", Alberto de Faria dizia ter conhecido "um homem que era um santo e um santo que era um homem"86. Quanto ao Dr. Simões Pereira, a quem conheceu já enfermo, elogiou-lhe o desinteresse e a competência, sublinhando o facto de ter ele assistido os epidemiados já adoentado, talvez devido ao esforço de um partejamento que fizera, seguido de uma "longa caminhada por noite frigidíssima" 87 . Todos estes pormenores favorecem a construção do herói, aquele que, sem pensar em si, vive numa contínua entrega.

Na primeira onda de exaltação, que percorreu aquilo que poderá classificar-se por processo de canonização dos dois médicos, esteve esquecido outro herói, de posição mais humilde, o barbeiro José Farias, caído no seu "arriscadíssimo posto de despiolhamento $[\ldots]$ em permanente contacto com o transmissor da doença" deixando viúva e quatro filhos.

Os funerais dos dois médicos mártires constituíram grandes manifestações de dor. Em circunstâncias normais, o desaparecimento do Dr. Simões Pereira seria sentidamente pranteado e teria um funeral imponente. Tinha somente quarenta e oito anos, longe ainda da idade em que a morte é encarada pelos outıos com a 
resignação nebulosa do inevitável. Era casado com D. Maria da Glória Calixto Marques da Silva, filha de António Marques da Silva, o dinâmico empresário que lançara as bases da Hidroeléctrica Serra da Estrela que abastecia de electricidade uma vasta região em torno de Seia. Deixou duas filhas ainda crianças. Quanto ao Dr. Amorim Fonseca, a sua morte, noutras circunstâncias, não teria despertado grande atenção fora de Loriga. Tinha sessenta e sete anos e levava uma vida modesta e apagada, sendo o seu desprendimento somente conhecido pelos que com ele conviviam.

As manifestações de pesar começaram pelos funerais. No do Dr. Simões Pereira juntaram-se cerca de três mil pessoas, provenientes de diversas zonas do país $^{89}$. Os ofícios fúnebres tiveram a presença de grande número de sacerdotes. Igualmente o funeral do Dr. Amorim, em Loriga, constituiu uma manifestação de dor, decorrendo com "extraordinária imponência" "90. Encontrava-se presente o Dr. Alberto José de Faria que, ao ter conhecimento, em Lisboa, da morte do subinspector, partira, para assistir ao funeral. Incumbira-se de representar o Dr. Ricardo Jorge que escrevera uma mensagem destinada a ser lida junto à sepultura. Como não conseguiu chegar a tempo, entendeu que as palavras do Director Geral tinham plena aplicação em relação ao Dr. Amorim, cujo funeral ocorreu dois dias depois.

Ricardo Jorge, após lembrar outros médicos que cairam vítimas dessa infecção ${ }^{91}$, termina com estas palavras, reveladoras do carácter de religiosidade de tais homenagens que se pretendia fossem o ponto de partida do culto a esses grandes homens:

Médico encanecido nas durezas morais do ofício, veterano das campanhas obscuras e cruciantes da luta epidémica, dobro o joelho perante estes restos sagrados, em nome de quantos trazem nos ombros o símbolo da cruzada redentora da existência humana, de todos os médicos que cada dia afirmam a crença e a obra duma investidura que é tradicionalmente um sacramento cívico. Essa luz guiadora faisca do sudário deste mártir do dever - embebamos nela os olhos húmidos para que se sequem as lágrimas e deixemo-la coar até ao coração para que se desentreve de negrumes ${ }^{92}$.

Os médicos ligados ao combate à epidemia discursaram à beira da sepultura. Em nome do povo de Loriga o professor Pedro de Almeida referiu-se à dívida desta povoação para com o seu velho médico.

Seria fastidioso enumerar as manifestações que foram tendo lugar nos tempos mais próximos: as missas, os discursos, os minutos de silêncio - essa "forma laicizada da oração" (G. Vincent, 1991:211), numa República laica que, neste 1927, também ela morria sem disso ter consciência. $O$ sétimo e o trigésimo dias após o funeral do Dr. Simões Pereira mereceram atenção especial. Em 27 de Maio foram rezadas na Igreja Matriz de Seia, ao mesmo tempo, sete missas ${ }^{93}$. Em 19 de Junho, na sede da Associação de Socorros Mútuos Senense, decorreu uma sessão de 
homenagem ao mesmo médico, com muitos discursos de enaltecimento proferidos por diversas individualidades. Foram guardados dois minutos de silêncio e, de seguida; procedeu-se ao descerramento do retrato do falecido, até aí coberto de crepes. Após a sessão, os assistentes dirigiram-se ao cemitério, sendo deposto no túmulo um ramo de flores naturais e rezados responsos fúnebres ${ }^{94}$.

Em Loriga, a 30 de Maio, ainda a viver-se o clima de epidemia, na sessão da Junta de Freguesia, depois de um voto de profundo sentimento em homenagem aos dois facultativos, foi decidido dar o nome do Dr. Amorim Fonseca a um pequeno largo da vila ${ }^{95}$.

Alguns meses depois, no dia 18 de Setembro, a trasladação dos restos mortais do Dr. Amorim Fonseca para Pedreira, Felgueiras, no concelho de Fafe, de onde era natural e onde viviam os seus familiares, serviu para, mais uma vez, homenagear, recordar, agradecer, chorar. Foi aproveitado o evento para, após a missa, se realizar a distribuição do donativo feito pelo Dr. Custódio que contemplou 88 pessoas carenciadas da freguesia.

O momento alto do dia deve ter sido quando, entre alas de povo emocionado que ainda não tivera tempo para recuperar das horas de agonia que vivera, foi conduzido o ataúde com o cadáver do médico que ali passara grande parte da sua vida, numa doação que foi até à morte. Estava coberto de flores, muitas delas trazidas pelas crianças das escolas ${ }^{96}$.

Como foi afirmado em sessão camarária, a morte dos dois mártires que enlutou, não só as suas famílias mas todo o concelho, "emocionou o país" ${ }^{\text {"97. }}$. Manifestações de solidariedade chegaram de diversos lugares, enviadas por desconhecidos que nunca haviam tido qualquer contacto com os desaparecidos. A subinspecção de saúde de Portimão, tendo deliberado lançar em acta um voto de profundo sentimento pela morte dos dois médicos, em mensagem enviada à Comissão Administrativa da Câmara Municipal pedia que fosse intérprete junto das famílias dessa deliberação ${ }^{98}$. O ministro de Portugal em Roma, Trindade Coelho, em telegrama dirigido ao Presidente da Câmara, requeria, em seu nome e no do pessoal da legação, que exprimisse às famílias dos médicos a dor pelo acontecido e a "profunda admiração"

Dadas as repercussões sentidas no resto do país, as homenagens aos dois médicos não ficaram circunscritas ao concelho de Seia. Uma comissão delegada do curso de que fazia parte o Dr. Simões Pereira e que havia reunido há pouco em Coimbra (onde o malogrado já não pôde estar presente), ficou de se avistar com os directores da faculdade de Medicina e dos Hospitais da Universidade, a fim de ser escolhido o local para a colocação de uma lápide que perpetuasse os nomes dos dois antigos alunos ${ }^{100}$. No Porto, na reunião da direcção da Associação Médica, em homenagem à memória dos dois colegas foi proposto "um voto de profundo pesar" pelo seu desaparecimento, voto que foi aprovado ${ }^{101}$. Na mesma cidade, na sessão de encerramennto do Congresso Nacional de Medicina que 
decorreu de 22 a 27 de Junho, os médicos presentes guardaram um minuto de silêncio à memória dos dois colegas mortos no "cumprimento do dever". Almeida Garrett, presidente da Comissão do Congresso, apresentou votos pela disseminação da assistência médico-sanitária, cuja falta, juntamente com o iletrismo, representavam a primeira causa da má situação sanitária ${ }^{102}$.

Mais uma vez higiene e escolarização apareciam a par, consideradas as grandes vias que conduziriam ao progresso. Em diversas manifestações em honra dos dois mortos homenageados e canonizados nos corações dos povos, é visível a ligação entre a escola e a higiene, entre o professor e o médico, os dois apóstolos de um mundo novo que muitos, a despeito das dificuldades e das desilusões - e das mudanças que talvez só os mais atentos poderiam prever - persistiam em querer construir. Na pretensão de que o futuro não esquecesse os nomes destes novos santos, as crianças eram chamadas a desempenhar um papel importante em todas as cerimónias.

A entidade cimeira da escola, o ministro da Instrução, agraciou com o grau de Comendador de Instrução e Benemerência os dois médicos ${ }^{103}$. No mesmo sentido a Liga Pró-Moral, com sede em Lisboa, pediu que, num dia previamente marcado, em todas as escolas do país os professores realizassem perante os alunos palestras onde fossem exaltados "os gestos heróicos desses dois soldados da paz"; nas escolas onde fosse possível, os seus retratos fossem expostos, tendo em vista perpetuar a memória dessas duas "vítimas do dever"; se convidasse um escritor português a fazer uma legenda que traduzisse, "pela eloquência da frase, a grandiosidade da abnegação desses dois mártires da ciência médica"104.

A 20 de Maio de 1928 o professorado primário do concelho levava a cabo uma grande homenagem às "duas vítimas do Dever". Como dizia a circular assinada pelo professor de Loriga, Pedro de Almeida, presidente do núcleo A Lutuosa ${ }^{105}$, "glorificar os mortos [...] é [...] dar uma sábia lição de moral e civismo." Assim, os professores cumpriam "um dos mais sagrados deveres, perpetuando a sua memória e inoculando na alma dos futuros cidadãos da Pátria o amor à ciência e à virtude, que são as únicas grandezas do Mundo"106.

A iniciativa da homenagem e os discursos proferidos são demonstrativos de como os professores mantinham em si a chama da religiosidade cívica, tão republicana, conscientes dos seus deveres como mediadores na "consagração pública e duradora dos grandes homens" e da função demopédica desse novo culto em ordem à "edificação do futuro" (F. Catroga, 1988:60-61).

A sessão de homenagem decorreu no salão do Tribunal Judicial, estando presentes todos os professores do concelho e alguns do vizinho concelho de Gouveia, alunos das escolas locais e pessoas das várias categorias sociais de Seia e povoações circunvizinhas. Os dois heróis presidiam à cerimónia através dos retratos enfeitados com flores trazidas pelas crianças, num ritual "dissimulador da morte" 
(F. Catroga, 1991:127), destinado a incutir veneração por esses "santos" apresentados como modelos.

O professor Rodolfo de Almeida Abreu, depois de afirmar que a Liga Pró-Moral, ao sugerir a homenagem, secundou o que o professorado já pensava fazer, apontou a memória dos médicos como um exemplo a seguir "Para quem desejar o resgate da humanidade pela Moral Social"107. Os dois mostraram quanto pode "a Ciência aliada ao Sacrifício". Asseverou que "é maior glória morrer no cumprimento do dever de defender a humanidade" 108 do que mostrar bravura no campo de batalha. O professor António Joaquim Pais, depois de lembrar Câmara Pestana, "imolando a sua vida para salvar a do seu semelhante", prestou homenagem aos heróis que "No combate à terrível epidemia que assolou a laboriosa vila de Loriga [...] escolheram o posto de maior perigo" 109 . Honrando a sua memória prestavam "ao nosso querido Portugal, nesta hora incerta do seu caminho, o maior e o mais assinalado serviço que um português pode fazer à sua Pátria" 10 .

Pedro de Almeida, que "viveu as horas trágicas da epidemia de Loriga, respirando uma atmosfera de terror e opressão", afirmou que "o professorado, que tem a verdadeira noção da missão que desempenha, sabe e compreende que glorificar os mortos, que se evidenciaram na vida, é praticar uma acção que se prolongará através dos tempos" "11. Elogiou a abnegação e o sacrifício do Dr. Amorim, obrigado a percorrer, quase diariamente, caminhos cheios de precipícios, para tratar dos seus doentes, compartilhando as suas dores e misérias. Quanto ao Dr. Simões Pereira, louvou a prontidão com que, ao dar-se conta da situação de perigo que se vivia, que podia estender-se a toda a região e, mesmo ao país, pediu imediatas providências. Os retratos dos médicos iriam ser colocados nas escolas de Seia e de Loriga, expostos à veneração dos alunos. Foi essa a recomendação feita pelo professor ao dirigir-se às crianças presentes: que venerassem sempre aqueles retratos, símbolos de altruismo e abnegação ${ }^{112}$.

Finda a sessão dirigiram-se para a Praça da República, onde se procedeu à cerimónia do lançamento da primeira pedra do monumento ao Dr. Simões Pereira, nascido da iniciativa do director de $A$ Voz da Serra que, para a concretizar, iniciara uma subscrição no seu jornal. As crianças, sempre presentes, lançaram flores naturais sobre a pedra ${ }^{113}$.

Também ao mais alto nível do país se reconheceu o sacrifício dos dois médicos. Para além da condecoração atribuída pelo Ministro da Instrução, foram ainda agraciados, a título póstumo, com o Grau de Cavaleiro da Ordem Militar da Torre e Espada de Valor, Lealdade e Mérito ${ }^{114}$.

Entretanto - e alguém chamou a atenção para o facto -, em todas estas expressões de respeito e de dor, era olvidado o nome do "herói obscuro" José Farias que era "sepultado nas catacumbas do Esquecimento o nome do Humilde" 115.

O culminar de tantas manifestações públicas seria na grande homenagem prestada em 1 e 2 de Dezembro de 1928. No primeiro dia, realizou-se a cerimónia da 
trasladação dos restos mortais do Dr. Simões Pereira, até ao dia anterior depositados no jazigo da família de João Dias, para a capela-mausoléu construída por iniciativa de António Marques da Silva que, deste modo, pretendeu homenagear o seu genro. $\mathrm{O}$ conjunto, em estilo $\mathrm{D}$. João $\mathrm{V}$, da autoria do arquitecto Alberto Vilaça, era constituído por duas partes distintas: a capela (com sacristia anexa) e o mausoléu com alpendre na dianteira. Juntamente com a urna foram depostos no mausoléu a maqueta do monumento que iria ser inaugurado no principal largo da vila em honra do falecido, uma ampliação do seu retrato e, rodeando uma imagem de Cristo crucificado, em prata, as fotografias do funeral e as condecorações que lhe haviam sido concedidas.

Ao cemitério havia afluído um grande número de pessoas vestidas de luto, provenientes de Seia e outras localidades, fazendo-se transportar muitas delas em automóveis e camionetas. Como não podia deixar de ser, houve discursos de elogio ao desaparecido, gerando-se um clima de forte emoção. Seguiram-se as exéquias na Igreja, decorada por armadores vindos propositadamente de Viseu. Desta cidade viera também o Orfeão do Asilo-Oficina de Santo António, que cantava os "misereres" em alternância com os responsos entoados por sacerdotes com paramentos fúnebres 116 .

No dia seguinte, nos Paços do Concelho, em cerimónia presidida pelo Governador Civil e com a presença do comandante da Guarnição, foi "a pública glorificação dos dois heróis", como se dizia no Diário de Notícias. Talvez fosse mais correcto falar em três heróis pois que, finalmente, alguém se lembrou de evocar, ainda que brevemente, o barbeiro José Farias. O Dr. António Dias, administrador do concelho, depois de lembrar o Dr. Amorim Fonseca, "o velho cenobita que tem um altar no coração de cada habitante" e o Dr. Simões Pereira, que, "sendo rico, era como um sacerdote da sua profissão", prestou homenagem ao barbeiro, soldado caído na mesma guerra dos outros. Lembrando que os mortos na guerra são tratados como iguais, pediu que fosse feita justiça a esse cuja morte deixou sem pão os quatro filhos e a sua companheira ${ }^{117}$.

Nesta cerimónia, a Faculdade de Medicina da Universidade de Coimbra, como escola de onde tinham saído os dois homenageados, quis estar presente, representada pelo Dr. Fernando de Almeida Ribeiro que afirmou o seu orgulho por ter sido na velha universidade que se formaram "tão nobres personalidades" $\mathrm{e}$ afirmou ser, com "maternal enternecimento pela memória de tão dilectos filhos seus", que a sua Faculdade juntava a tantos outros "o sinceríssimo contingente da sua admiração e da sua grata saudade" 118 .

Após o discurso do governador civil que, em nome do Governo da República, trazia a solidariedade à vila de Seia, mais uma vez foram descerrados os retratos dos dois médicos, enquanto lá fora, no Largo das Obras, a Banda 15 de Agosto tocava o Hino Nacional. Terminada a sessão, organizou-se o cortejo em direcção 
à Praça da República, onde iria ser inaugurado o busto do Dr. Simões Pereira, esculpido por Costa Mota.

$\mathrm{Na}$ verdade, o culto ao médico não se satisfazia com as visitas ao cemitério. Era preciso que ele continuasse no espaço dos vivos, na praça principal da sua terra, tornado imortal pelos seus actos e exemplo para as futuras gerações, pois que, como dizia Comte, "Os vivos são sempre, e cada vez mais, governados pelos mortos: tal é a lei fundamental da ordem humana"119.

Simões Pereira tornara-se a figura mais venerada de Seia, aquela que reunia em si o maior consenso. No final dos anos trinta isso é ainda visível. Criado então um colégio que possibilitava aos filhos de Seia a frequência do ensino secundário, sem terem de se deslocar para longe, como seu patrono foi escolhido - não podia ser outro - o Dr. Simões Pereira ${ }^{120}$.

Os habitantes de Loriga não quiseram ficar atrás nesse processo de "presentificação da memória dos grandes homens no espaço público e aberto"121. Doze anos após os trágicos acontecimentos, demonstraram que o tempo [ainda] não apagara a dívida de gratidão e os mortos permaneciam com força suficiente para unir vontades e despertar emoções. Por subscrição pública e auxílio da Câmara Municipal ${ }^{122}$, conseguiram levantar um busto do Dr. Amorim no largo que tem o seu nome. No dia 28 de Maio de 1939 milhares de pessoas reuniram-se para a inauguração e, mais uma vez, concentrar-se, num minuto de silêncio. Todavia, não pretenderam honrar somente o velho médico que com eles vivera durante trinta e três anos. Quiseram unir num monumento a trindade formada pelos três mártires do dever profissional, cujos nomes gravaram numa placa de mármore: Amorim da Fonseca, Simões Pereira, José Farias.

A família do mais pobre teve de contentar-se com este tipo de agradecimento público, pois que, embora fossem encetadas algumas diligências no sentido de lhe ser atribuída uma pensão, tal nunca foi conseguido ${ }^{123}$.

$\mathrm{Na}$ verdade, como escrevia Avelino Cunhal a propósito de todas estas cerimónias de rememoração, os heróis dos novos tempos já não eram os mesmos de antigamente - "heróis da espada, da política, do pensamento, da religião, todos os que souberam vencer, ou todos os que souberam morrer entre gritos rubros de vitória ou entre consolações divinas de uma bem-aventurança". Os novos heróis eram obscuros, praticando "o dever pelo dever, o bem pelo bem,[...], sem público e sem consolação fora da sua alma". Os heróis do presente eram o cientista que, no seu laboratório se deixava corroer pelas emanações do rádio, a irmãzinha de caridade enclausurada numa gafaria, o médico que, longe do olhar do mundo, luta contra a dor e contra a morte, de casa em casa, de pobreza em pobreza ${ }^{124}$.

As horas de recordar os mortos, sendo, naturalmente, de melancolia, conduzem a interrogações. O político republicano Domingos Pereira (que em diversas ocasiões chefiara o ministério ${ }^{125}$ ), presente na inauguração do busto ao Dr. Simões Pereira, de quem era amigo, talvez desalentado depois de tantas esperanças não 
cumpridas e perante as "exibições de um artificialismo fraudulento, tanto em voga na hora mundial que decorre", questionava-se, frente ao desaparecimento sem sentido de um amigo dotado de sincera bondade, sobre "Que mistério preside à vida, que parece caprichoso e arbitrário". Não encontrava resposta. Pois que "uma muralha milenária, tão velha como os mundos, uma esfinge silenciosa, $[\ldots]$ permanece inabalável e surda aos meus desesperados apelos, aos desesperados apelos da pobre Humanidade" 126 .

Todas estas cerimónias resultam duma patética tentativa de procurar que aqueles de quem gostamos escapem à morte. Pura ilusão. Poucas décadas passadas após a tragédia, o busto do Dr. Simões Pereira era retirado da praça principal e remetido para uma rua mais sossegada onde pudesse, em paz, ser completamente esquecido.

Loriga, que sofreu na sua carne, ainda encontrou em si uma memória suficientemente forte para, em Maio de 1977, homenagear as vítimas de cinquenta anos atrás.

\section{CONCLUSÃO}

Termino este trabalho com a consciência de estar a fazer uma história a partir do "centro", escapando-me, porventura, muito do que se passou nessa "periferia" forjada pela experiência. À falta de fontes credíveis, a intuição torna-se, por vezes, o fio condutor na apreensão de impressões e sentimentos.

Atendendo ao número de mortos registados na epidemia de Loriga, poderá causar espanto todo esse alarido, a nós que estamos acostumados a digerir com emoção passageira acidentes de aviação envolvendo centenas de vítimas. Creio que todo o pânico que se gerou foi resultante do choque entre as esperanças interiorizadas, através da divulgação científica empreendida nos últimos anos, e a impotência em evitar a propagação do morbo, do qual foram vítimas os próprios sacerdotes dessa mesma ciência. Na verdade, o avanço da civilização tecnocientífica tornou mais difícil a aceitação da morte. Para a sociedade do século XX, viver já não é uma sorte, como acontecia num passado recente; tornou-se num direito (Antoine Prost, 1991:107).

Numa sociedade que, acima de tudo, preza a saúde, o doente vê-se remetido para o limiar da marginalidade, inspirando um misto de piedade e de receio. Isolado, para seu próprio bem ou em nome da "utilidade social", à mercê da instituição controladora, perde a sua autonomia, passando a viver num universo de proibições e de regras de que desconhece os porquês. O mesmo acontece aos que, de algum modo, podem inspirar a suspeita (quantas vezes sem qualquer fundamento) de que transportam em si a semente do mal. 
No difícil equilíbrio entre o público e o privado, aquele sobrepõe-se sempre que o interesse geral o exige. À classe dominante, detentora do saber/poder, caberá avaliar e interpretar esse interesse geral e, em consonância com isso, ditar a lei que exclui alguns de gozar os tão proclamados direitos individuais, o que será tanto mais fácil quanto mais os excluídos acumularem em si outros sintomas de marginalidade, isto é, outros sinais de culpa. O viver nos bas-fonds da cidade é indício suficiente para se ser olhado como um perigo para a tranquilidade pública. Daí o arrebanhar dessas dezenas de pessoas que, nos subúrbios de Lisboa, foram isoladas num hospital-prisão, consideradas indignas de uma vida normal[izada] por "desvio" no caminho regulamentado pelo "Grande Irmão".

Valorizando-se a vida, cresce a admiração por aqueles que, por generosidade, sacrificam a sua pelos outros. $O$ foco da veneração religiosa passou a incidir sobre um tipo de santo diferente do anterior, não sendo tanto aquele que vive a procurar a perfeição na solidão do seu deserto, mas aquele que despreza a sua própria vida numa entrega aos outros. Compreende-se, assim, o culto prestado aos médicos caídos no cumprimento do seu dever, considerados heróis e mártires.

A epidemia teve outros heróis que não passaram as fronteiras de Loriga - 0 caso de José Farias é disso exemplo - e, naturalmente, outros cujo sacrifício não passou a porta da sua casa ou o limiar da sua consciência. Homens e mulheres que trataram de filhos, irmãos, pais e sogros, vizinhos que se auxiliaram, numa solidariedade que falou mais alto que a prudência. Alguns terão perdido a vida nesse esquecimento do eu em favor do outro e os seus nomes não chegaram ao futuro, nosso presente.

Heróis foram igualmente os médicos Custódio de Azevedo e Mota Feliz que, já conscientes do tipo da doença, aceitaram partir para a linha de demarcação entre o viver e o morrer.

Quanto ao conceito de martírio, tantas vezes ligado aos nomes dos dois médicos mortos, poderemos estender o seu sentido e considerar que todas as vítimas da povoação sinistrada ou fora dela, tocadas de uma forma directa ou indirecta foram mártires, vítimas das condições habitacionais, de hábitos enraizados, do isolamento, da ignorância, enfim, das diversas formas que a pobreza assume. Apanhadas num turbilhão que destruiu a inocência de vidas, mergulhadas na resignação silenciosa de quem não espera que a história algum dia venha a ocupar-se delas. 


\section{NOTAS}

' Para ilustrar o prestígio da medicina e do médico o autor faz referência à cidade de Lyon com cento e doze ruas, tendo nomes de médicos.

${ }^{2}$ Ricardo Jorge. In Ana Leonor Pereira e João Rui Pita, "Liturgia higienista no século XIX", Revista de História das Ideias, vol. 15, Coimbra, Faculdade de Letras, 1993, p. 453.

${ }^{3}$ Sobre a construção do "homem novo" leia-se Fernando Catroga, O Republicanismo em Portugal - da formação ao 5 de Outubro de 1910, Coimbra, Faculdade de Letras, 1991, pp. 449$-464$.

4 "A Reforma da Instrução Primária", in Educação Nacional, Ano XV, n. $759,2 / 04 / 1911$, pp. 267-276.

${ }^{5}$ Sobre este assunto veja-se Yves-Marie Bercé, "Os soldados de Napoleão vencidos pelo tifo", in As Doenças Têm História (apres. de Jacques Le Goff), Lisboa, Ed. Terramar, 1991, pp. 161-172.

"Idem, "O que é o tifo", in As doenças têm história, cit., pp. 173-174.

${ }^{7}$ V. Fattorusso e O. Ritter, Vademecum Clinico del Medico Practico del Sintoma a la Receta, Ed. "El Ateneo", S. A., Barcelona, 1976, p. 1033 e Medicina Interna (dir. C. Rozman), vol. II, Ed. Marín, pp. 978 e seg., Barcelona, 1975. Sobre a doença ver ainda Grande Enciclopédia Portuguesa e Brasileira, vol. 31, pp.637-640. Fernando da Silva Correia aponta os meses Março, Abril e Maio, - seguindo-se os do Inverno -, como os de maior mortalidade ocasionada por tifo. Fernando da Silva Correia, Portugal Sanitário, Direcção Geral de Saúde, 1938, p. 211.

${ }^{8}$ Ricardo Jorge, "Vítimas da Profissão. Simões Pereira e Amorim Fonseca", A Medicina Contemporânea, Ano XLV, n. ${ }^{\circ} 24,12 / 06 / 1927$, p. 185. Trata-se de uma mensagem escrita para ser lida junto à sepultura do primeiro médico que caiu vítima da epidemia de Loriga. O jornal A Ocasião (que se publicou durante algum tempo em Seia, devido à suspensão temporária de A Voz da Serra), inseriu nas suas colunas as palavras do conhecido higienista. Ano I, n. 2 , 11/06/1927, p. 5, col. 2.

${ }^{9}$ José Alberto de Faria, "Os nossos que foram vencidos", A Medicina Contemporânea, cit., p. 186

${ }^{10}$ Em 1920 Loriga tinha 2316 hab. Censo da População de Portugal no $1 .^{\circ}$ de Dezembro de 1920, Imprensa Nacional, p. 102. O Anuário Comercial de Portugal de 1926 dá-lhe 3278 , o que é um exagero, pois que, consultando o Censo de 1930, encontram-se 2421 . Censo da População de Portugal, Dez 1930, Parte I, Imprensa Nacional, 1933, p. 110.

" Anuario Comercial de Portugal, Lisboa, Empreza do Annuario Commercial, 1926, p. 2173..

${ }^{12}$ Carminda Cavaco e Isabel Marques, "Os vales de Loriga e de Alvoco na Serra da Estrela. Estudo de Geografia Humana”. Separata de Finisterra, Revista Portuguesa de Geografia, vol. 1-2, Lisboa, 1966, p. 210 . Em 1944 a distribuição dos 3096 ha de Loriga seria a seguinte: 182 (milho), 57 (batata), 4 (centeio), 1 (vinha), 318 (pinhal), 19 (olival), 147 (castanheiros), 2300 (baldios) e 68 (área social). Eugénio Manuel de Melo, "Inquérito à estrutura social do concelho de Seia", Altitude, Ano IV, n. ${ }^{\circ}$ a 3, 1944, p. 26.

${ }^{13}$ Foi assim que o Dr. Alberto de Faria viu Loriga quando, pela primeira vez, aqui chegou (José Alberto de Faria, art. cit., p. 185).

${ }^{14}$ A Voz da Serra, Ano VI, n. ${ }^{\circ}$ 125, p. 1, col. 1. No estudo publicado na revista Altitude, atrás citado, em 1944 diz-se que 119 famílias de Loriga viviam em casas consideradas boas; $200 \mathrm{em}$ casas regulares e 365 em casas más (Eugénio Manuel de Melo, ob. cit., p. 48).

${ }^{15} \mathrm{O}$ Anuário Comercial refere a existência de seis fábricas embora, mais adiante, indique os nomes de oito. Quanto aos operários alude a cerca de mil (Anuario Comercial de Portugal, 1926, Empreza do Anuario Comercial, Lisboa, 1926, p. 2173). O número de operários é mani- 
festamente exagerado. A acreditar em outra fonte haveria, em 1944, 143 famílias de operários (Eugénio Manuel de Melo, ob. cit., pp. 31-32). Mesmo tendo em conta que, em muitas famílias, vários dos seus elementos seriam operários, estamos ainda longe dos mil. Contudo, lembre-se que muita gente, sobretudo mulheres, efectuava trabalho para as fábricas, no domicílio.

${ }^{16}$ Ruy díAlva [António Dias], "Terras de Lendas", A Voz da Serra, Ano IV, n. 148 , $8 / 04 / 1928$, p. 3, col. 3. Também, num discurso, o mesmo António Dias, administrador do concelho, se lhe refere nestes termos "colmeia", "formigueiro humano" (Ibidem, Ano X, n. ${ }^{\circ} 161$, $3 / 02 / 1929$, p. 4 , col. 3).

${ }^{17} \mathrm{O}$ auxílio foi conseguido graças aos esforços de Pedro de Almeida, professor em Loriga desde há muitos anos e muito conceituado entre os colegas, não só do concelho mas dos limítrofes). (Ceia Fraternal, Ano IV, n. $111,10 / 05 / 1919$, p. 3, col. 3).

${ }^{18}$ Arq. Junta de Freg., Livro de Actas das Sessões, 1/09/1935, ff. 155. Eugénio Manuel de Melo, no estudo citado, referente a 1944, conta 97 famílias de operários e 77 de trabalhadores rurais nada possuindo, nem sequer uma casa. Os indigentes seriam 41. Quanto ao número de crianças até aos 12 anos encontradas em estado de miséria e abandono seriam 204. Tal situação estava longe de ser excepcional no concelho, visto que, segundo o mesmo estudo, existiriam, nesse estado de carência, 263 crianças em S. Romão e 226 em Seia (E. M. Melo, ob. cit.).

${ }^{19}$ Ibidem, 1/01/1935, f. 150.

${ }^{20}$ Segundo o Relatório dos serviços das circunscrições no ano de 1927, Boletim de Trabalho Industrial, Lisboa, Imprensa Nacional, 1931, p. 84. Também o jornal $O$ Hermínio, que se publicava em Gouveia, se refere à crise nos lanifícios ( $O$ Hermínio, 12/06/1927, p. 1, col. 1-2).

${ }^{21}$ Diário de Notícias, Ano LXIV, n. ${ }^{\circ} 22577,3 / 12 / 1927$, p. 2, col. 7. A referência aos dois operários vindos da Covilhã encontra-se igualmente numa "Nota Oficiosa" de 17/06/1927, assinada por João da Mota Feliz, Delegado da Inspecção de Epidemias (In Arq. da Junta de Freguesia, Loriga, Correspondência recebida, doc $\mathrm{n} .{ }^{\circ} 106$ ). A nota foi publicada na imprensa da época. Com o título "Epidemiologia, A Epidemia de Loriga", pode ser lida em A Medicina Contemporânea, Ano XLV, n. ${ }^{\circ} 26,26 / 06 / 1927$, p. 205. Entre os óbitos registados em Loriga, no mês de Outubro de 1926, encontra-se o de um indivíduo do sexo masculino, natural de uma freguesia do concelho da Covilhã (Arq Paroquial de Loriga, Livro dos Óbitos).

${ }^{22}$ Nota oficiosa de 17/06/1927, cit.

${ }^{23}$ Telegrama do administrador do concelho dirigido ao gov. civil (A. M. Seia, Livro da correspondência dirigida ao governo civil, 28/04/1927, n. ${ }^{\circ} 53$ ). A referência ao maior número de vítimas entre a população feminina - que será comprovada adiante - encontra-se num relatório sobre a epidemia, da autoria do administrador António Dias e enviado ao governador civil, a pedido deste, em finais de Junho. No livro da correspondência dirigida ao gov. civil, em $28 / 06 / 1927$, existe referência a esse relatório. Contudo, em pesquisa feita no arquivo distrital da Guarda, na correspondência dirigida ao governo civil, não foi encontrado, como, aliás, não foi encontrada qualquer correspondência sobre este e outros assuntos. Conheço o relatório através de uma cópia dactilografada que me foi facultada e, embora seja de crer que estará de acordo com o original - não se desvia muito do que é dito em ofícios e telegramas -, prefiro guiar-me por estes. Contudo, a aceitar a cópia do relatório, considero de algum interesse as insinuações de que elementos da burguesia da povoação afectada pela epidemia, numa primeira fase, não deram importância à moléstia, pois que, os inícios do outono e da primavera eram frequentemente perigosos para as ditas "classes miseráveis".

${ }^{24}$ Nota oficiosa, de 17/06/1927, cit.

${ }_{25}$ De acordo com o correspondente de Loriga do Novidades, Ano LXII, n. ${ }^{\circ} 9664$, 23/05/1927, p. 4, col. 2.

${ }^{26}$ Sessão de 30 de Abril de 1927. A. da Junta de Freg. Loriga, Livro das Sessões.

27 "O tifo exantemático em Loriga - Uma nota oficiosa da Direcção Geral de Saúde", Novidades, Ano LXII, n. ${ }^{\circ}$ 9660, 19/05/1927, p. 2, col. 3. 
28 Telegrama de 28/04/1927, Arq. Munic. de Seia, Livro da Correspondência para o Governo Civil, 1927.

${ }^{29}$ Of. $\mathbf{n}^{\circ} 56,57$ e 58 . Ibidem.

3) "Nota oficiosa", Novidades, 19/05/1927, cit.

${ }^{31}$ A Ocasião, Ano I, n. ${ }^{\circ}$ 1, 15/05/1927.

32 "Correspondência de Loriga", Novidades, 23/05/1927, cit.

3.3 "Nota oficiosa", Novidades, 19/05/1927, cit.

${ }^{34}$ Idem, ibidem, Novidades, 19/05/1927, cit. Um telegrama do administrador dá-nos conta de que, nesse dia 7 de Maio, o Dr. Simões Pereira sentira a urgência das providências que se impunham. no sentido de isolar os tifosos. No telegrama citado, pedia-se ao governador civil que fossem requisitadas ao Ministério da Guerra 50 camas completas que poderiam ser fornecidas pela unidade militar mais próxima. (A. Munic. Seia, Livro da Correspondência para o Governo Civil., 7/05/1927, n. ${ }^{\circ} 68$ ).

${ }^{35}$ Carta publicada em $A$ Voz da Serra, Ano X, n. ${ }^{\circ} 161,3 / 02 / 1929$, p. p. 6, col. 2

${ }^{36}$ O Século, Ano XLVIII, n. ${ }^{\circ}$ 16226, 11/05/1927, "Uma grave epidemia”, 11/05/1927, p. 1, col. 5

37 "Nota Oficiosa Epidemia de Loriga", 17/06/1927, cit.

${ }^{36} \mathrm{O}$ nome da capela não aparece nos diversos documentos relacionados com a epidemia. A referência é-lhe feita em sessão da Junta de Freguesia, de 30/01/1929,quando se tratou de o pequeno edifício voltar a ser entregue à comissão encarregada das obras.

${ }^{39}$ Nota oficiosa, cit. Vários jornais deram a conhecer as medidas tomadas para vencer a doença, existindo, por vezes, algumas discrepâncias. Assim, O Século, Ano XLVIII, n. ${ }^{\circ} 16226$, $11 / 05 / 1927$, p. 1, col. 5 refere 100 camas em vez de 50. Em nota oficiosa da Direcção Geral de Saúde, publicada pelo Novidades, são fornecidas informações detalhadas sobre o assunto ("O Tifo Exantemático em Loriga - Uma nota oficiosa da Direç̧ão geral de Saúde", Novidades, Ano LXII, n. ${ }^{\circ}$ 9660, 19/05/1927, p. 2, col. 3).

${ }^{40}$ Tel. de 9/05/1927, A. M. Seia, Livro da Correspondência, cit., n. ${ }^{\circ} 70$.

${ }^{41}$ Of. de 16/05/1927. Idem. ibidem, n. ${ }^{0} 75$. No relatório a que foi feita referência o administrador dá a entender que os trabalhos de adaptação do hospital foram demorados devido à incompreensão acerca das vantagens do isolamento. No entanto, ele próprio, em ofício de 10 de Maio, anuncia o início do funcionamento do hospital para o dia seguinte (Livro da Correspondência, cit., 10/05/1927, n. ${ }^{\circ} 71$ ).

${ }^{42}$ Segundo o administrador de Seia (Ibidem, 16/05/1927, n. ${ }^{\circ} 75$ ).

43 José Alberto de Faria, art. cit., p. 186.

${ }^{44}$ O adjectivo "bondoso" aplicado em relação ao Dr. Amorim Fonseca não tem a ver somente com as circunstâncias em que a sua morte ocorreu. Na acta da sessão da Câmara Municipal de Seia de 16 de Janeiro de 1907 ficou exarado um louvor a este médico, "pela forma a mais humanitaria e carinhosa" como tratou os doentes da Cabeça (uma povoação vizinha de Loriga), atacados por uma epidemia de varíola (A. M. S. , Actas das sessões da Câmara Mun).

${ }^{45} \mathrm{O}$ Novidades, em correspondência de Loriga, datada de 20 de Maio, apresentava uma descrição do que se passava em Loriga, com queixas acerca da actuação do inspector interino (Novidades, 23/05/1927, p. 4, col. 3). O administrador do concelho, em ofício ao govennador civil, pedia que se procedesse judicialmente contra o autor de "insidiosas notícias" publicadas no Diário de Noticias e que atingiam o subinspector interino o qual, segundo o administrador, se sacrificava passando noites sem dormir (Livro de Correspondência para o Governo Civil, 17/05/1927).

${ }^{46} \mathrm{O}$ problema encontrou solução em reunião de 19 de Maio, precisamente no dia em que morreu o Dr. Simões Pereira (A. M. S., Actas das Sessões da Câmara Municipal, 19/05/1927). 
${ }^{47}$ Cf. $O$ Século, Ano XLVIII, n. ${ }^{\circ} 16355,17 / 09 / 1927$, p. 2 , col. 4.

${ }^{48} O$ Século, Ano XLVIII, n. ${ }^{\circ} 16241,26 / 05 / 1927$, p. 1, col. 6.

${ }^{49}$ João da Mota Feliz, "Dois martires...", A Voz da Serra, Ano X, n. ${ }^{\circ}$ 160, 1/12/1928, p. 6, col. 1.

${ }^{50}$ Ricardo Jorge, "Vítimas da profissão - Simões Pereira e Amorim Fonseca", A Medicina Contemporânea, Ano XLV, p. 185. Fernando da Silva Correia, num "Quadro de Honra" com os nomes de médicos vítimas de epidemias, entre 1834 e 1929, aponta os nomes de 17 médicos vítimas de tifo exantemático (Fernando da Silva Correia, ob. cit., pp. 513-514.

${ }^{51}$ Novidades, Ano LXII, n. ${ }^{\circ}$ 9664, 23/05/1927, p. 4, col. 2.

${ }^{52}$ Embora tivesse havido neste mês oito funerais, num deles a morte ocorreu fora de Loriga (Arq. Par. Loriga, Livros dos óbitos, 1925, 1926, 1927).

${ }^{53}$ A acreditar no correspondente de Loriga para $O$ Século, Ano XLVIII, n. ${ }^{\circ} 16.252$, 6/06/1927, p. 1, col. 2.

${ }^{54}$ De acordo com informações retiradas do Livro de assentos de óbitos da freguesia de Loriga.

55 "Nota oficiosa" de 17/06/1927, cit.. A Medicina Contemporânea, que publicou esta nota, faz referência a 3 fábricas, mas deve tratar-se de gralha.

${ }^{56}$ Incidentes dessa natureza não são de estranhar, pelo que será de aceitar essa informação retirada da "cópia do relatório" enviado pelo administrador.

${ }^{57}$ Isso pode ser comprovado através dos assentos paroquiais onde se assinalam os óbitos ocorridos no hospital. Mas o privilégio de ter continuado em sua casa não significa que a assistência prestada ao médico fosse de qualidade superior. Em diversas ocasiões se insinuou o estado de desamparo a que fora votado. O correspondente do jornal Novidades lamentava-se do abandono a que estava votado o Dr. Amorim da Fonseca que estava há dois dias sem assistência médica (isto antes da chegada do Dr. Custódio). (Novidades, n. ${ }^{\circ} 9664,23 / 05 / 1927$, p. 2 , col. 3 ). Esse abandono devia ser largamente comentado pois que, doze anos depois, se encontram referências ao mesmo assunto, num discurso proferido em homenagem ao médico ( $A$ Voz da Serra, Ano XX, n. ${ }^{\circ} 403,15 / 06 / 1939$, p. 2, col. 2).

${ }^{58}$ A Acreditar na "cópia do relatório", cit.

${ }^{59}$ Novidades, Ano LXII, n. ${ }^{\circ} 9665,24 / 05 / 1927$, p. 4, col. 3.

${ }^{60}$ Idem, ibidem, p. 168. Foi respeitada a ortografia da tradução brasileira.

${ }^{61}$ Novidades, Ano LXII, n. ${ }^{\circ}$ 9664, 23/05/1927, p. 4, col. 3.

${ }^{62} \mathrm{O}$ próprio professor teria contado esse episódio, segundo testemunha dessa época.

${ }^{63}$ De acordo com as palavras proferidas alguns anos depois pelo professor Pedro de Almeida (A Voz da Serra, Ano XX, in. ${ }^{\circ} 403,15 / 06 / 1939$, p. 2, col. 2). Segundo uma testemunha que no ano da epidemia frequentava a $4^{a}$ classe, as crianças que se encontravam nessas condições continuavam a ter aulas, devido aos exames que se aproximavam. Contudo, eram tomadas precauções, sendo sujeitas a desinfecção.

${ }^{64}$ Arq. da Junta de Freg. Loriga. O rascunho encontra-se entre outros documentos (não numerados) respeitantes à epidemia, na pasta da Correspondência Recebida respeitante a esse período.

${ }^{65}$ A Ocasião, Ano I, n. ${ }^{\circ} 1,15 / 05 / 1927$, p. 3, col. 1

${ }^{66}$ Novidades, Ano LXII, n. ${ }^{\circ} 9660,19 / 05 / 1927$, p. 2 , col. 3

${ }^{67}$ O Século, Ano XLVIII, n. ${ }^{\circ}$ 16236, "A epidemia de Loriga", 21/05/1927, p. 1, col. 3

${ }^{68} \mathrm{Ibidem}$, Ano XLVIII, n. ${ }^{\circ} 16237$, "Vítimas do dever", p. 1, col. 3

${ }^{69}$ A Voz da Serra, Ano XX, n. ${ }^{\circ} 389,25 / 01 / 39$, p. 2 , col. 3.

${ }^{70}$ O Seculo, n. ${ }^{\circ} 16234,19 / 05 / 1927$, p. 1, col. 5. 
${ }^{71}$ Novidades, Ano XLII, n. ${ }^{\circ} 9664,23 / 05 / 1927$, p. 4, col. 2.

${ }^{72}$ Alusão ao "Panóptico", criação de Jeremias Bentham, que pretende ilustrar uma sociedade onde nada escapa ao olhar de um vigilante. Podemos conhecer as dificuldades em controlar a população loriguense através de um telegrama do administrador concelhio dirigido ao governo civil em 16 de Maio. O administrador considera "Absolutamente impossível fazer respeitar posturas sanitárias sem ter auxiliares". Pede que lhe seja enviada polícia, "imediatamente" (Livro da Correspondência..., cit., n..$^{\circ} 77$ ).

${ }^{73}$ Muitos rapazinhos - hoje chamar-lhes-íamos crianças - saíam de Loriga, buscando na cintura industrial de Lisboa a realização de sonhos de uma vida melhor. Sacavém recebeu uma numerosa colónia de loriguenses.

${ }^{74}$ O Século, Ano XLVIII, n. ${ }^{\circ} 16233,18 / 05 / 1927$, p. 8, col. 3.

${ }^{75}$ Gazeta de Coimbra, Ano XVI, n. ${ }^{\circ} 2051,7 / 06 / 1927$, p. 1, col. 4.

${ }^{76} \mathrm{~A}$ correspondência dirigida à autoridade sanitária de Loriga encontra-se, sem numeração, anexa à pasta da Correspondência Recebida pela Junta de Freguesia de Loriga.

${ }^{77}$ O Século, Ano XLVIII, n. ${ }^{\circ} 16252,6 / 06 / 1927$, p. 1, col. 2

${ }^{78}$ Gazeta de Coimbra, Ano XVI, n. ${ }^{\circ} 2045,24 / 05 / 1927$, p. 2 , col. 5.

${ }^{79}$ Diário de Notícias, Ano LXIII, n. ${ }^{\circ} 22026,24 / 05 / 1927$, p. 2, col. 5.

${ }^{80}$ Ibidem, Ano LXIII, n. ${ }^{\circ} 22029,27 / 05 / 1927$, p. 1, col. 3.

${ }^{81}$ Nota publicada em 25/05/1927. In A Ocasião, Ano I, n. ${ }^{\circ} 2,11 / 06 / 1927$, p. 7, col. 1. Também $O$ Século faz referência a essa nota oficiosa e à conveniência de o público não se deixar influenciar por "notícias tendenciosas" (O Século, n. ${ }^{\circ}$ 16.241, 25/05/1927, p. 1, col. 6).

O semanário $O$ Hermínio, que se publicava em Gouveia, apresentava aos leitores uma lista de "instruções" que deveriam seguir para se precaverem contra a epidemia. $O$ melhor desinfectante para o corpo era o "sublimado corrosivo a 1 por mil". O mesmo soluto podia servir para as roupas que seriam aí mantidas durante 24 horas. Lysol ou Creolina a 5 por cento poderiam usarse para desinfectar as mãos, as roupas e objectos. Para retretes e bacios aconselhava-se cloreto de cálcio ou sulfato de cobre. As lavagens do corpo e das roupas deviam ser frequente e, quanto aos farrapos velhos, as pessoas eram aconselhadas a queimá-los. As roupas lavadas teriam de ser bem passadas a ferro, em especial nas pregas, onde o piolho podia alojar-se. Para destruir o insecto aconselhava-se o corte "rente" dos cabelos, os quais seriam queimados depois de regados com petróleo ou gasolina. O Hermínio, Ano XXX, n. ${ }^{\circ} 1528,22 / 05 / 1927$, p. 1, col. 4. No mesmo jornal, num anúncio com título "Tifo exantemático", aconselhava-se o uso de Eleborina (que podia adquirir-se na Farmácia Feliz) para extinção do piolho.Ibidem, p. 3, col. 1.

${ }^{82}$ Nota de 30/05/1927. In A Ocasião, n. ${ }^{\circ} 2$, cit, p. 7, col. 2

${ }^{83}$ Diário de Notícias, Ano LXIII, n. ${ }^{\circ} 22035,2 / 06 / 1927$, p. 1 , col. 3.

${ }^{84}$ Diário de Notícias, Ano LXIII, n. ${ }^{\circ} 22034,1 / 06 / 1927$, p. 2, col. 7.

${ }^{85}$ Diário de Notícias, Ano LXIII, n. ${ }^{\circ} 22035,2 / 06 / 1927$, p. 1 , col. 3.

86 "Os nossos que foram vencidos", A Medicina Contemporânea, 12/06/1927, p. 186

${ }^{87}$ Idem, ibidem.

${ }^{88}$ Mais de um ano passado, perante as homenagens feitas aos médicos, alguém lamentava o esquecimento em que tinha caído o pobre barbeiro ( $A$ Voz da Serra, Ano IX, n. ${ }^{\circ} 151$, 23/06/1928, p. 8, col. 1).

${ }^{89}$ A Ocasião, n. $.^{\circ} 2,11 / 06 / 1927$. Este número é dedicado à morte do Dr. Simões Pereira

${ }^{90}$ O Século, n. $.^{\circ} 16238,23 / 06 / 1927$, p. 1 , col. 4

${ }^{91}$ Fernando da Silva Correia apresenta um "Quadro de Honra" de que fazem parte os nomes dos médicos caídos no cumprimento do seu dever. Aí podemos encontrar dezassete médicos vítimas de tifo exantemático. In Portugal Sanitário, cit. , pp. 513, 514. 
${ }^{92}$ A Ocasião, Ano I, n. ${ }^{\circ} 2,11 / 06 / 1927$, p. 6, col. 1. As palavras de Ricardo Jorge foram publicadas em A Medicina Contemporânea (Ricardo Jorge, "Vítimas da Profissão - Simões Pereira e Amorim Fonseca", A Med. Cont., Ano XLV, 12/06/1927, p. 185).

${ }_{93}^{3}$ A Ocasião, n. ${ }^{\circ}$ 2, cit., p. 4, col. 1.

${ }^{94}$ A Ocasião, Ano I, n. ${ }^{\circ}$ 3, 22/07/1927, p. 1, $2,3$.

${ }^{55}$ Arq. da Junta de Freguesia de Loriga. Actas das sessões.

${ }^{96}$ O Século, Ano XLVIII, n. ${ }^{\circ} 16358,20 / 09 / 1927$, p. 3, col. 3. Segundo um convite dirigido à Comissão Administrativa pelo professor Pedro de Almeida que, nestas circunstâncias, representou $O$ Século, este jornal também deu o seu contributo monetário para as pessoas carenciadas de Loriga. Arq. da J. Freg. Correspondência recebida.

${ }^{97}$ Arq. Mun. de Seia, Actas das Sessões da C. M. S. , 26/05/1927.

${ }^{98}$ Idem, ibidem, 16/06/1927.

${ }^{99}$ Idem, Livro da Correspondência expedida pela C. M., 30/05/1927.

${ }^{100}$ A Ocasião, n. ${ }^{\circ} 2,11 / 06 / 1927$, p. 7, col. 3.

${ }^{101}$ Idem, ibidem.

${ }^{102}$ A Medicina Contemporânea, n. ${ }^{\circ}$ 26, 26/06/1927, p. 202.

${ }^{103}$ A Ocasião, n. ${ }^{\circ} 2$, cit., p. 3, col. 3.

${ }^{104}$ Idem, p. 4, col. 1.

${ }^{105}$ A Lutuosa dos Professores Primários era um organismo de segurança social e resultara da iniciativa dos núcleos regionais de professores (António Nóvoa, ob. cit., p. 638).

${ }^{106}$ Circular aos professores, com data de 3/05/1928. In A voz da Serra, Ano IX, n. ${ }^{\circ} 150$, 13/05/1928, p. 4.

${ }^{107}$ A Voz da Serra, Ano IX, n. ${ }^{\circ} 151,23 / 06 / 1928$, p. 2, col. 1.

${ }^{108}$ Idem, col. 2.

${ }^{109}$ Idem, p. 3, col. 1

110) Idem, ibidem

"II Idem ibidem, p. 3, col. 1.

112 Idem, p. p. 4, col. 3.

${ }^{113}$ Idem, p. 7, col. 1.

${ }^{114}$ A Voz da Serra, Ano IX, n. ${ }^{\circ} 149,29 / 04 / 1928$, p. 1, col. 3.

115 A. Gomes, "A epidemia de Loriga - as vítimas do dever profissional”, idem, n. ${ }^{\circ} 151$, cit., p. 8 , col. 1 .

${ }^{116}$ Idem, 3/02, 1929, p. 1-3.

${ }^{117}$ Idem, p. 5, col. 2.

${ }^{118}$ Idem, p. 5, col. 3. Da Faculdade de Medicina esteve igualmente presente o Dr. Geraldino de Brites. Pertenciam ao curso do Dr. Simões Pereira. Desse curso estiveram presentes igualmente os Drs. Custódio de Almeida Henriques, Abel Pais Cabral e João Vaz Antunes.

${ }^{119}$ In Jean Touchard, História das Ideias Políticas, Lisboa, Publ. Europa-América, Vol VI, p. 92

${ }^{120}$ A Voz da Serra, n. ${ }^{\circ} 410,5 / 09 / 1939$.

${ }^{121}$ Ver Fernando Catroga, A Militância..., cit., em especial o subcapítulo "As estátuas dentro da cidade", pp. 980-989.

122 De acordo com as afirmações proferidas por Herculano Leitão que falou em nome da comissão promotora do monumento. (A Voz da Serra, Ano XX, n. ${ }^{\circ} 403,15 / 06 / 1939$, p. 2, col. 2). 
${ }^{12.3}$ Segundo afirmou Pedro de Almeida na cerimónia da inauguração - e esta afirmação envolve uma acusação a alguém - "a isso se opôs a criminosa declaração de que, quando foi requisitado, já estava contagiado" (Idem, ibidem, p. 3, col. 3).

${ }^{124}$ Avelino Cunhal, "Os novos ídolos", A Voz da Serra, Ano X, n. ${ }^{\circ}$ 160, 1/12/1928, p. 3.

${ }^{125}$ A identificação deste amigo de Simões Pereira e assíduo visitante de Seia é feita pel' O Século, Ano XLIX, n. ${ }^{\circ} 16789,3 / 12 / 1928$, p. 8, col. 3. Também o Diário de Notícias se lhe referia no mesmo dia, p. 2, col. 4.

${ }^{126}$ A Voz da Serra, Ano X, n. ${ }^{\circ} 161,3 / 02 / 1927$, p. 8-9.

\section{BIBLIOGRAFIA}

\section{FONTES MANUSCRITAS}

Arq. da Junta de Freg. Loriga:

Actas das Sessões, 1927, 1929, 1935

Livro da Correspondência Recebida

Arq. Paroquial de Loriga:

Livro dos Assentos de Óbitos, 1925, 1926, 1927

Arq. da C. M. Seia:

Actas das Sessões, 1927

Livro da Correspondência do administrador para o Governo Civil, 1927

Livro da Correspondência expedida pela C.M., 1927

\section{FONTES IMPRESSAS}

Publicações Periódicas:

Annuario Commercial de Portugal (1926)

Boletim do Trabalho Industrial (1931)

Ceia Fraternal (1919)

Diário de Notícias $(1927,1928)$

Educação Nacional, A (1911)

Gazeta de Coimbra,(1927)

Hermínio, O (1927)

Medicina Contemporânea, A (1927)

Novidades (1927)

Ocasião, A (1927)

Século, $O$ (1927)

Voz da Serra, A (1927, 1928, 1939) 


\section{OUTRAS FONTES E OBRAS DE CONSULTA}

ARIÈS, Philippe (1993), Essais de Mémoire, Paris, Éditions du Seuil.

BERCÉ, Yves-Marie (1991), "Os soldados de Napoleão vencidos pelo tifo", As Doenças Têm História (coord. Jacques Le Goff), Ed. Terramar, Lisboa.

CATROGA, Fernando (1988), A Militância Laica e a Descristianização da Morte, Coimbra.

CATROGA, Fernando (1991), O Republicanismo em Portugal da Formação ao 5 de Outubro de 1910, vol. II, Coimbra, Faculdade de Letras.

CATROGA, Fernando "Revolução e secularização dos cemitérios em Portugal (inumistas e cremacionistas), Atitudes Perante a Morte (coord. António Matias Coelho), (1991), Coimbra, Livraria Minerva.

CAVACO, Carminda e MARQUES, Isabel (1966), "Os Vales de Loriga e de Alvoco da Serra. Estudo de Geografia Humana", Finisterra, Revista Portuguesa de Geografia, vol. I, n. ${ }^{\circ}$, p. 188-239.

Censo da População de Portugal no $1 .^{\circ}$ de Dezembro de 1920, Imprensa Nacional.

Censo da População de Portugal, Dezembro 1930 (1933), Imprensa Nacional.

CORREIA, Eduardo da Silva (1938), Portugal Sanitário, Dir. Geral de Saúde.

FATTORUSSO, V. e RITTER, O. (1976), Vademecum clinico del medico practico del sintoma a la receta, Ed. "El Ateneo", S. A., Barcelona.

FOUCAULT, Michel (1994), Naissance de la Clinique, Paris, Quadrigue/P.U.F.

FOUCAULT, Michel (1987), Vigiar e Punir, Petrópolis, Vozes.

GARRETT, António de Almeida (1958), "Ricardo Jorge e sua obra de higiene pública e epidemiologia", separata de Portugal Médico, Vol. XLII, n. ${ }^{\circ} 5$.

MELO, Eugénio Manuel de, "Inquérito à estrutura social do concelho de Seia" (1944), Revista Altitude, 1 a 3, Guarda.

MOURA, Maria Lúcia de Brito (1996), Viver e Morrer em Gouveia nos Alvores do Século XX, Viseu.

NIZARD, Georges (1994), L'hôpital en turbulence, Toulouse, Ed. Privat.

NÓVOA, António (1987), Le Temps des Professeurs, Lisboa, INIC.

PEREIRA, Ana Leonor e PITA, João Rui (1993), "Liturgia Higienista no século XIX", Revista de História das Ideias, vol. 15, p. 437-559.

PITA, João Rui, vd. PEREIRA, Ana Leonor.

PROST, Antoine (1991), "Fronteiras e espaços do privado", História da Vida Privada (dir. Philippe Ariès e Georges Duby), vol. V, Porto, Ed. Afrontamento.

RITTER, O., vd. FATTORUSSO, V.

ROZMAN, C. (1975), Medicina Interna, vol. II, Barcelona, Ed. Marin.

TOUCHARD, Jean (1970), História das Ideias Políticas, Vol. VI, Lisboa, Publ. Europa-América.

VAQUINHAS, Irene Maria (1992), "O conceito de "decadência fisiológica da raça" e o desenvolvimento do desporto em Portugal (finais do século XIX / Princípios do século XX", Revista de História das Ideias, vol. 14, p. 365-388.

VINCENT, Gérard (1991), "Uma história do segredo", História da Vida Privada (dir. Philippe Ariès e Georges Duby), vol. V, Porto, Ed. Afrontamento. 